Florida International University FIU Digital Commons

FIU Electronic Theses and Dissertations

University Graduate School

$7-5-2013$

\title{
Barrier Island Response to Sea Level Rise in North Carolina
}

Evan D. Cook

ecook017@fiu.edu

DOI: $10.25148 /$ etd.FI13080710

Follow this and additional works at: https://digitalcommons.fiu.edu/etd

Part of the Environmental Sciences Commons, and the Geomorphology Commons

\section{Recommended Citation}

Cook, Evan D., "Barrier Island Response to Sea Level Rise in North Carolina" (2013). FIU Electronic Theses and Dissertations. 920. https://digitalcommons.fiu.edu/etd/920

This work is brought to you for free and open access by the University Graduate School at FIU Digital Commons. It has been accepted for inclusion in FIU Electronic Theses and Dissertations by an authorized administrator of FIU Digital Commons. For more information, please contact dcc@fiu.edu. 


\section{FLORIDA INTERNATIONAL UNIVERSITY}

Miami, FL

BARRIER ISLAND RESPONSE TO SEA LEVEL RISE IN NORTH CAROLINA

A thesis draft submitted in partial fulfillment

of the requirements for the degree of

MASTER OF SCIENCE

in

ENVIRONMENTAL STUDIES

by

Evan D. Cook

2013 
To: Dean Kenneth G. Furton

College of Arts and Sciences

This thesis, written by Evan D. Cook, and entitled Barrier Island Response to Sea Level Rise, having been approved in respect to style and intellectual content, is referred to you for judgment.

We have read this thesis and recommend that it be approved.

$\begin{array}{r}\hline \text { Michael Ross } \\ \hline \text { Stephen Leatherman } \\ \hline \text { Keqi Zhang, Major Professor }\end{array}$

Date of Defense: July 5, 2013

The thesis of Evan D. Cook is approved.

\begin{tabular}{r} 
Dean Kenneth G. Furton \\
College of Arts and Sciences \\
\hline Dean Lakshmi N. Reddi \\
University Graduate School
\end{tabular}

Florida International University, 2013 
ABSTRACT OF THE THESIS

BARRIER ISLAND RESPONSE TO SEA LEVEL RISE IN NORTH CAROLINA

by

\section{Evan D. Cook}

Miami, Florida

\section{Professor Keqi Zhang, Major Professor}

The state of North Carolina is home to some of the most spectacular barrier islands in the world. These features are constantly shifting, impacted by waves, tides, and wind. Studies of the Outer Banks, North Carolina have resulted in varied results, but a detailed analysis of the barrier system as a whole is lacking. Using historic topographic surveys (T-sheets) from the $19^{\text {th }}$, the positions of various barrier segments were analyzed in relation to modern imagery.

Changes in area, width, and center line locations were evaluated over the past 150 years. In total, 74 percent of modern transects have decreased in area. Total reductions in size were $130 \mathrm{~km}^{2}$ for the study period. Mean centerlines as a function of migration showed that 53 percent of segments were demonstrating directional movement away from the ocean. The average movement towards the bay between modern and historic centerlines was 8 meters. Thusly, barrier islands in North Carolina are demonstrating both decreases in total area and directional movement inland in response to sea level rise. 


\section{TABLE OF CONTENTS}

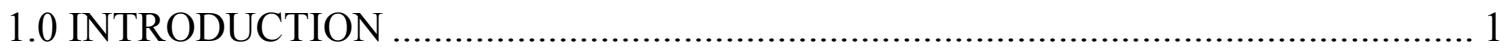

1.1 Brief Background .......................................................................................... 1

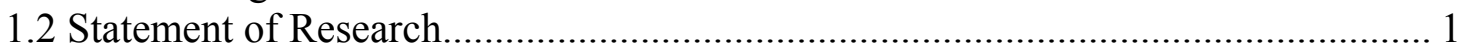

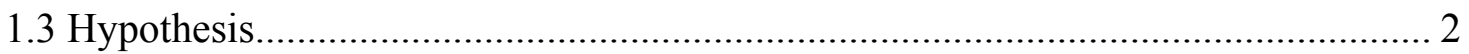

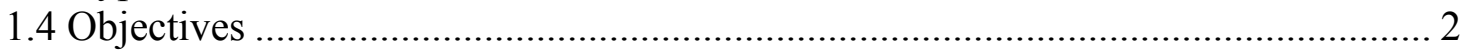

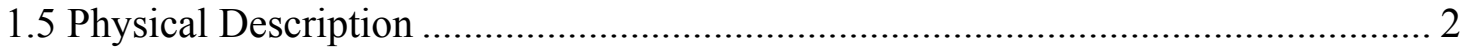

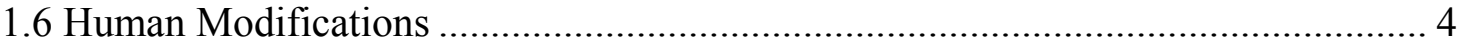

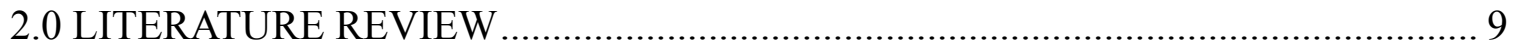

2.1 Barrier Island Migration ...................................................................... 9

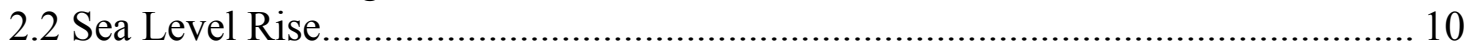

2.3 Outer Banks of North Carolina .......................................................................... 11

2.4 Topographic survey utilization in literature ...................................................... 13

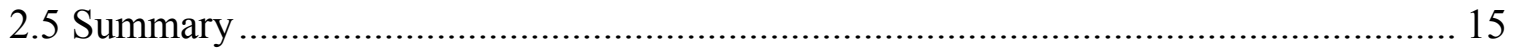

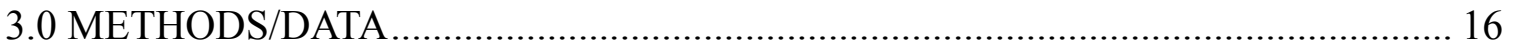

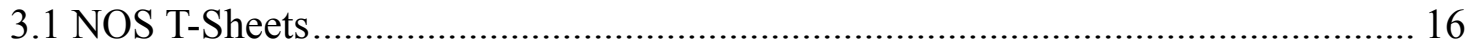

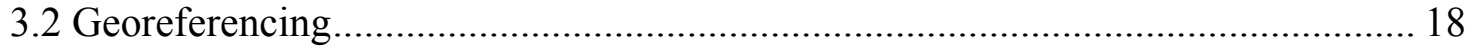

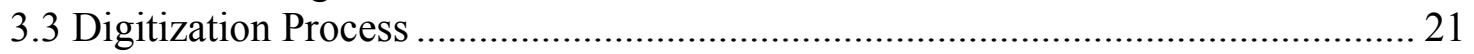

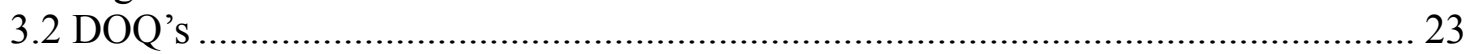

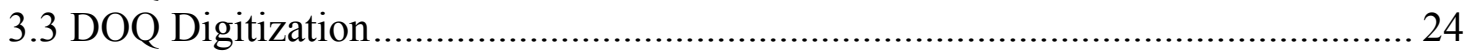

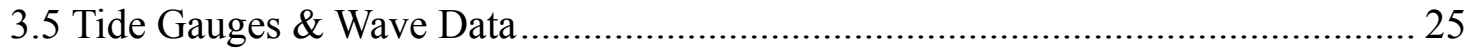

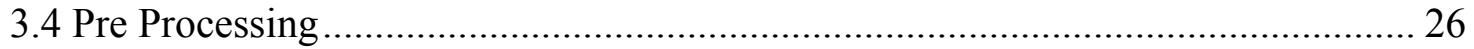

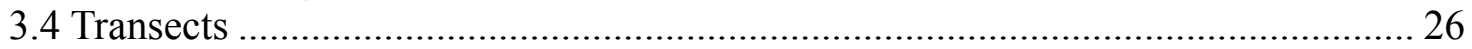

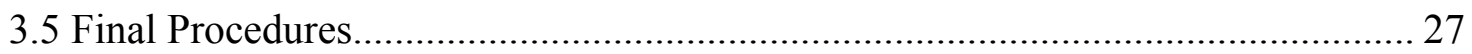

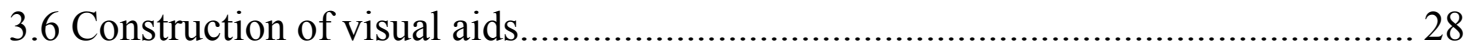

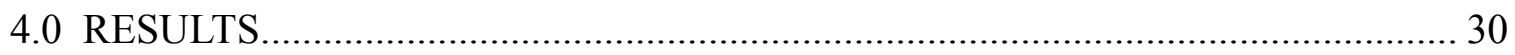

4.1 Oregon Inlet to Currituck Sound............................................................................ 30

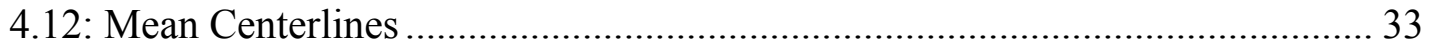

4.2 Oregon Inlet to Cape Hatteras............................................................................ 36

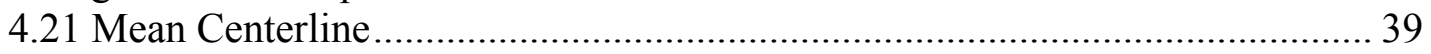

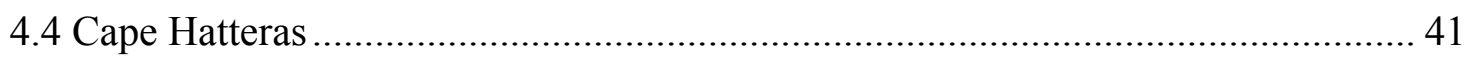

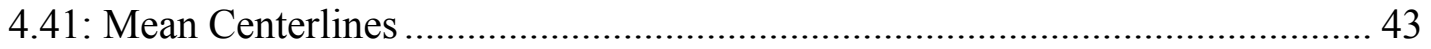

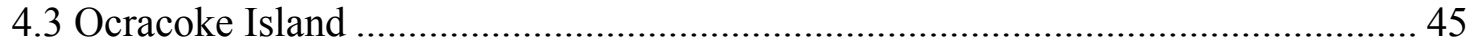

4.31 Ocracoke Island Mean Centerlines ……………............................................ 47

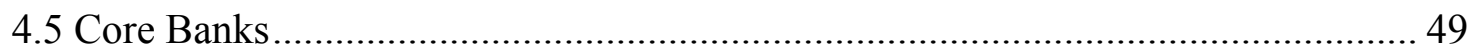

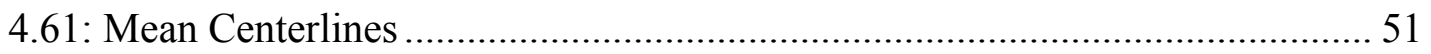

4.6 Cape Lookout to Shackleford Banks ................................................................. 53 


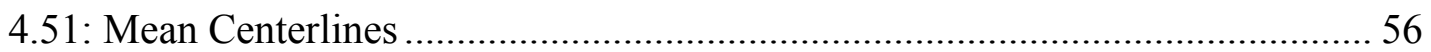

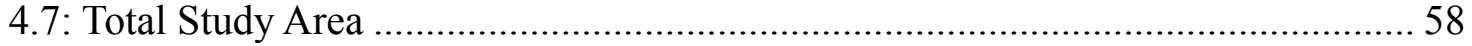

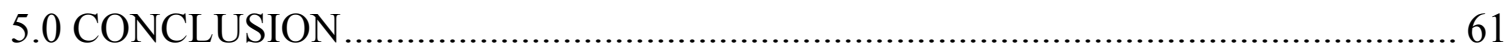

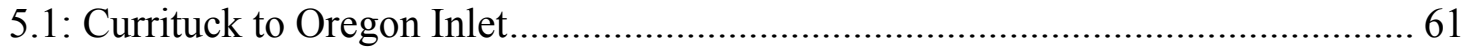

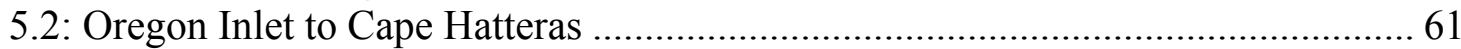

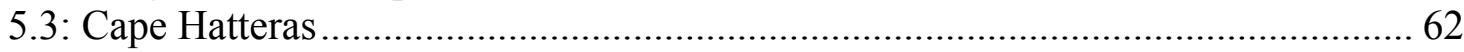

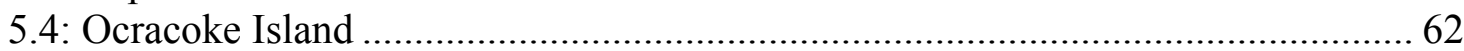

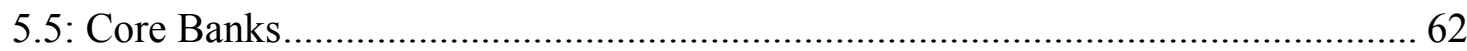

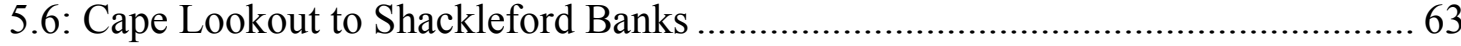

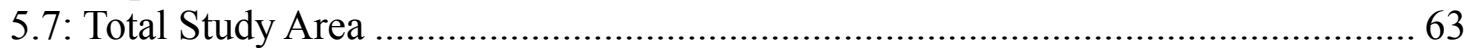

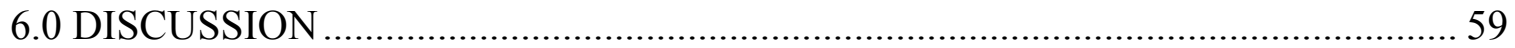

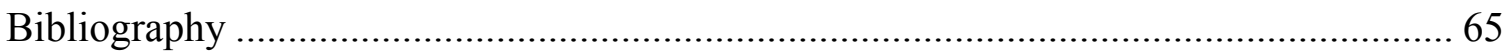




\section{LIST OF FIGURES}

\section{FIGURE}

PAGE

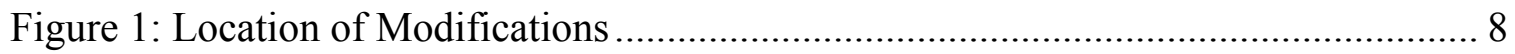

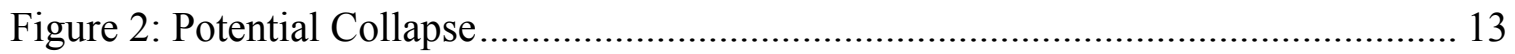

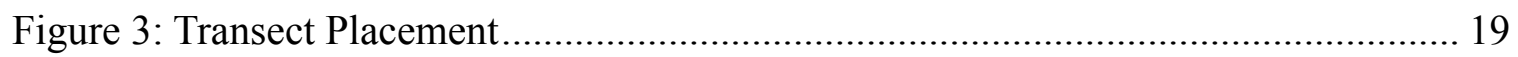

Figure 4: Demonstration of the digitization process .............................................. 21

Figure 5: Example of marsh island exclusion in T-sheet 381(2) ................................ 22

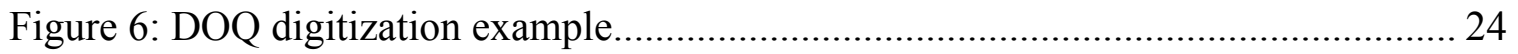

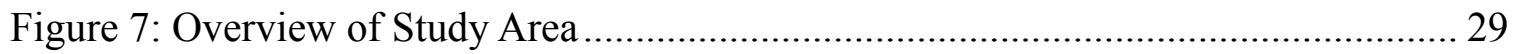

Figure 8: Transects, Oregon Inlet to Currituck ..................................................... 31

Figure 9: Mean centerline locations, Oregon Inlet to Currituck ................................... 35

Figure 10: Transects, Oregon Inlet to Cape Hatteras ................................................... 38

Figure 11: Mean centerline locations, Oregon Inlet to Cape Hatteras ............................ 40

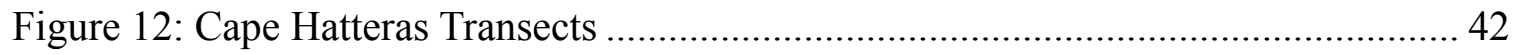

Figure 13: Example of bayside modification to residential areas in Cape Hatteras ......... 43

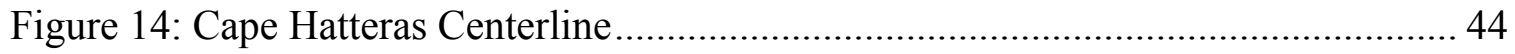

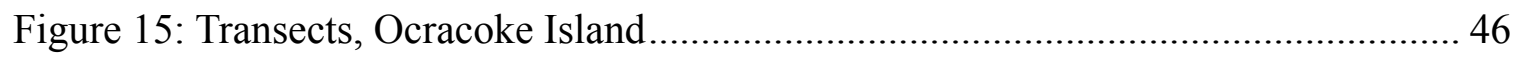

Figure 16: Centerline locations, Ocracoke Island ............................................... 48

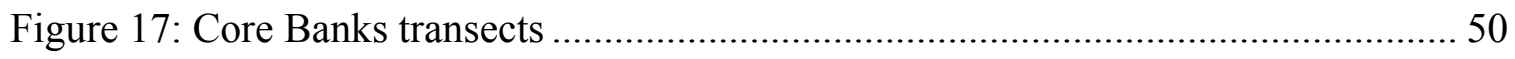

Figure 18: Mean Centerline locations, Core Banks ................................................. 52

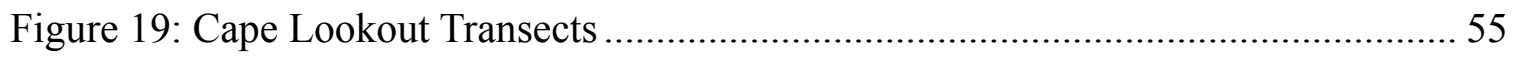

Figure 20: Mean centerline locations for Cape Lookout .......................................... 57 


\section{LIST OF TABLES}

TABLE

PAGE

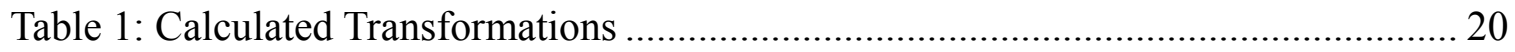

Table 2: Location of tide gauges, dates they were installed, and derived SLR trends...... 25

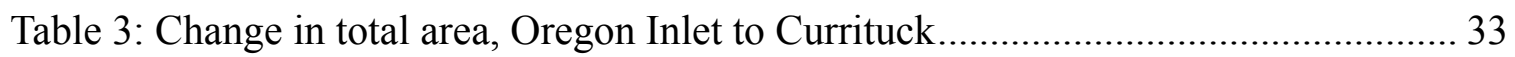

Table 4: Difference in mean centerline position Oregon Inlet to Currituck .................... 34

Table 5: Change in Area and Width, Oregon Inlet to Cape Hatteras .............................. 37

Table 6: Centerline change, Oregon Inlet to Cape Hatteras............................................ 39

Table 7: Change in total area, Cape Hatteras ............................................................ 41

Table 8: Cape Hatteras Mean Centerline Movement ................................................... 44

Table 9: Change in area and width, Ocracoke Island................................................ 45

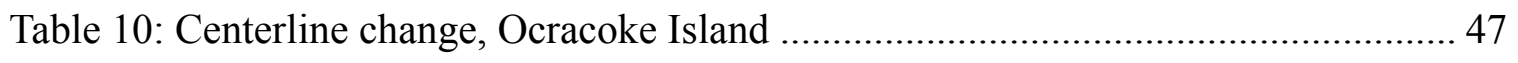

Table 11: Summary statistics for Core Banks ...................................................... 50

Table 12: Mean centerline change, Core Banks...................................................... 53

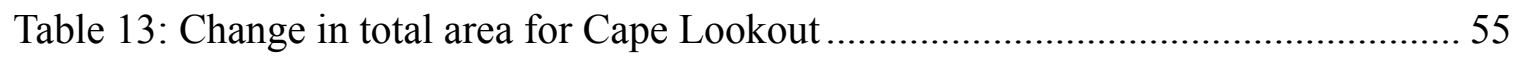

Table 14: Centerline Movement, Cape Lookout.................................................... 58

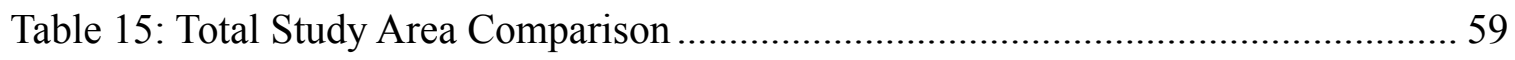




\subsection{INTRODUCTION}

\subsection{Brief Background}

Barrier islands in the United States are a favorite place for both living and visiting. They are highly vulnerable to erosion and flooding because they are constantly subjected to the impacts of waves, tides, storms, and being comprised of sand and finer sediments. The collision course of population increases and development in the face of accelerated sea level rise (SLR) due to global climate change make barrier islands even more vulnerable in the future than they are today. In order to predict the impacts of climate changes, especially SLR, on barrier islands, it is essential to understand the process and mechanism of changes to barrier islands as they have responded to SLR in the past. The Outer Banks of North Carolina provide an idea location for studying the response of barrier islands to SLR.

\subsection{Statement of Research}

The focus of this research is to address a number of questions relating to sea level rise and barrier island migration in North Carolina that have not been previously examined. Specifically, where is erosion or accretion occurring? What locations are experiencing an increase or decrease in total area and width? Have these resulted in shape changes of the barrier island segments? What are the changes at these locations in response to SLR and wave action, and has the entire barrier island system migrated in the past 150 years? The quantitative study of the pattern of historical barrier island changes aids in prediction of how barrier islands will respond to future sea level rise. 


\subsection{Hypothesis}

The Outer Banks of North Carolina have migrated in a dynamic fashion over the last 150 years. Great storms can create inlets, leading to segmentation of the barrier islands, but most of these microtidal inlets eventually close, and the shoreline straightens and moves landward. The alternative is that the barrier segments are shrinking both in total area and width, and have not demonstrated migration.

\subsection{Objectives}

- $\quad$ Provide a structured methodology for utilizing historic topographic surveys from unreferenced, scanned, raw images.

- Assess changes in barrier island area, width, and shape

- Classify locations based on amount of change

\subsection{Physical Description}

Barrier islands are a common coastal landform along the United States Atlantic and Gulf Coasts. According to Pompe (1999), shorelines on barrier islands amount to approximately 2,700 miles in length. They are also home to a substantial population of more than 1.4 million people, with a 14\% increase from 1990-2000 (Zhang et al, 2011). These landforms are mainly present in microtidal (0-2 meters) and mesotidal (2-4 m) environments and are theorized to have formed in a number of different ways, with spit accretion and segmentation; beach ridge submergence, and deposition of sediments on underwater bar systems (Leatherman 1988). Microtidal barrier islands are dominated by wave action, and are long and narrow in width (Leatherman 1988) 
North Carolina barrier islands have a total acreage of 146,000 and a total length of 324 miles (Leatherman, 1988). The state's coastal region can be broken into two different zones; the southern and northern, which are distinguished by the geological age of their sediments. The southern portion reflects mainly older substrates deposited from the Miocene to Cretaceous periods. The northern coastal zone reflects mainly Pliocene and quaternary formations (Riggs et al, 2011). Quaternary Period materials such as mud, sand, and peat that were laid down from the high variability in sea level. The northernmost portion is part of the Albemarle Embayment, which is slowly subsiding. Residing in the North Carolina coastal plain is the Outer Banks and Core Banks. The chain of mainly narrow barrier features extends from the mid portion of the state of North Carolina up to Virginia, nearly $210 \mathrm{~km}$ in length (Everts and Gibson, 1983).

It is home to 57,555 residents with upwards of 220,000 during peak tourist season and is a valuable source of income for the state (Kleckley, 2012) with 2.5 billion dollars in 2009 brought in from the coastal counties. Eighty five percent of that amount can be attributed to the banks themselves (Riggs et al 2011). Home to two federally protected areas (Cape Hatteras National Seashore and Pea Island National Wildlife Refuge) and a number of historic sights of national significance (i.e., Wright Brothers National Memorial), the islands stretch from the Virginia border near Currituck Sound southward to the approximate location of Hatteras Inlet nestled on the 175 mile long outer coastal plain (Riggs et al., 2009).

The Outer Banks can be classified into two types of islands; simple and complex. Simple barriers are low on sand supply, narrow, and extremely dynamic and susceptible 
to inlet breaching (locations such as Ocracroke, etc.). Complex islands are usually higher in elevation and wider, composed of older sedimentary deposits as present in locations such as Cape Hatteras (Riggs et al., 2009). The elevations in the Outer Banks are generally low, with the exception of the massive sand dunes that reach an approximate height of 30 meters in Kill Devil Hills (Clark et al., 1912). In Carteret, Currituck, Dare, Hyde, Pamlico, and Tyrell Counties, the average elevation in some portions is only .3 to .6 meters (Riggs et al, 2011). The barrier islands are also one of the most impacted by storms (tropical and nor'easter) in the United States with an average of 6.2 tropical systems passing within 200 miles each decade (Riggs, et al., 2011).

The development and creation of both the Outer Banks and the sounds themselves is debated, but core samples taken in Pamlico Sound indicate riverine like sediments in valley formations, suggesting that at one time there may have been a large series of deltas present. As sea level rose, exposed ridges located on the edge of this theorized delta remained above MSL while the inner marshes became submerged (Mallison et al., 2005). Today the bay side is dominated by two shallow sounds, Albemarle and Pamlico. These sounds are the location for four major river mouths, the Chowan, Tar, Roanoke, and the Neuse. Currently, the Outer Banks are separated from north to south by a series of inlets, Oregon inlet, Hatteras Inlet, Ocracoke Inlet, Drum Inlet, and Cape Fear Inlet.

\subsection{Human Modifications}

As population on the islands increased, there became an explicit need to develop infrastructure to support the influx of people. What was an isolated community nestled 
far from the coast and only reachable by boat, quickly changed with the construction of North Carolina State Highway 12 in 1952. Ten years later, construction of the Herbert C. Bonner bridge provided critical vehicle access to communities south of Oregon Inlet.; Rodanthe; Avon; Buxton; and Hatteras.(Riggs et al 2011).

Over time, many inlets have formed along the Outer Banks coast and closed as a result of their small size and wave induced sediment transport. As far back as 3000 B.P., the Outer Banks has estimated to have had upwards of 40 inlets (Mallinson et al., 2008). In fact, they are so common that $70-85 \%$ of the total area have ".. had one or more inlets at some time during their past 500 year history (Riggs et al., 2007).” The few inlets that remain are constantly dredged to allow movement of boat traffic. These include Oregon inlet, Hatteras Inlet, Ocracoke Inlet, Darden's Inlet, and Beaufort Inlet (Western Carolina University, http://psds.wcu.edu/1038.asp). Oregon Inlet (which has experienced significant migration) is the location of a jetty built in 1989-1991 on its south side of Pea Island. This jetty's blockage of the longshore transport coupled with the desired conservation of a natural state in the protected areas of Pea Island National Wildlife Refuge has caused significant issues. Since its installation, high rates of erosion at the northern (or southern) side of the inlet have occurred. In general, the continued variability in shoreline location has created maintenance costs of upwards of 92 million dollars since 1983 (Riggs and Ames, 2009).

Additional modifications of the Outer Banks have been in the construction of the barrier dune ridges in the southern portions north of Cape Hatteras by the Works Progress Administration and Civilian Conservation Corps in the 1930's to combat storm impacts. 
The dunes required extensive maintenance and reconstruction in order to protect infrastructure located behind them (mainly State Road 12) (Riggs et al., 2009). Although the dunes have served their main purpose of protecting the roadway, they prevent overwash during storm events. Since this process is integral to increasing the size and elevation of the barrier island, the island width has shown significant decline (Riggs et al., 2011). In 1984 a General Management Plan was created to outline shore protection strategies and the locations where they should be practiced. It stated that "natural processes would be allowed to occur by halting future stabilization measures" with three exceptions: (1) Highway 12, (2) Ocracoke village, and (3) Cape Hatteras Lighthouse (Vincent, 2003, p. 27 in Riggs et al., 2009).

Beach nourishment is “...currently the most practiced method of coastal protection and restoration in the United States (Campbell et al 2004)", and has occurred in many locations throughout the North Carolina Coast (see Figure 1). Nourishment overall is quite expensive, with a recent project in Southeastern North Carolina costing 25 million dollars (Withers and Queram 2012). In addition, extensive sand fencing and planting of vegetation was performed between 1933 and 1940 by the National Park Service and the Civilian Conservation Corps (Croft, 1934, Dunbar, 1958, in Dolan, 1986). According to Riggs et al (2011), beach nourishment prior to the 1990's was applied for only a 12 mile stretch. This has expanded to include additional areas such as those affected by the maintenance of inlets where hard structures and dredging blocked sediment transport (i.e. Oregon and Beaufort Inlets). From north to south, the locations that have received additional sand are Cape Lookout (2005), Isabel Breach (2003), Buxton (1962-1999), Cape Hatteras (1966-1973), Pea Island (1990-2004), and Nags 
Head (2001-2002). The main purpose of these episodes of nourishment is to protect infrastructure such as the historic lighthouses on Cape Lookout and Hatteras, and to close inlets and protect roads (Western Carolina University).

The alternative to beach nourishment is the utilization of hard structures such as bulkheads and groins. These strategies were implemented throughout the barrier island chain until they were banned by North Carolina state legislation in 1985. The majority of these projects exist in and around Oregon Inlet (in an effort to maintain a navigable channel) and a groin field located south of Cape Fear (Riggs et al 2011). The hard structures are mainly comprised of rock or concrete, and some older wood structures. In total, they cover approximately $3.3 \mathrm{~km}$ of shoreline. The total length of locations practicing sand bagging is unknown, but based on aerial photos there are approximately 130 locations utilizing them including the state of North Carolina, cities of Nags Head and Kitty Hawk, and a large number of beachfront property owners (Western Carolina University). 


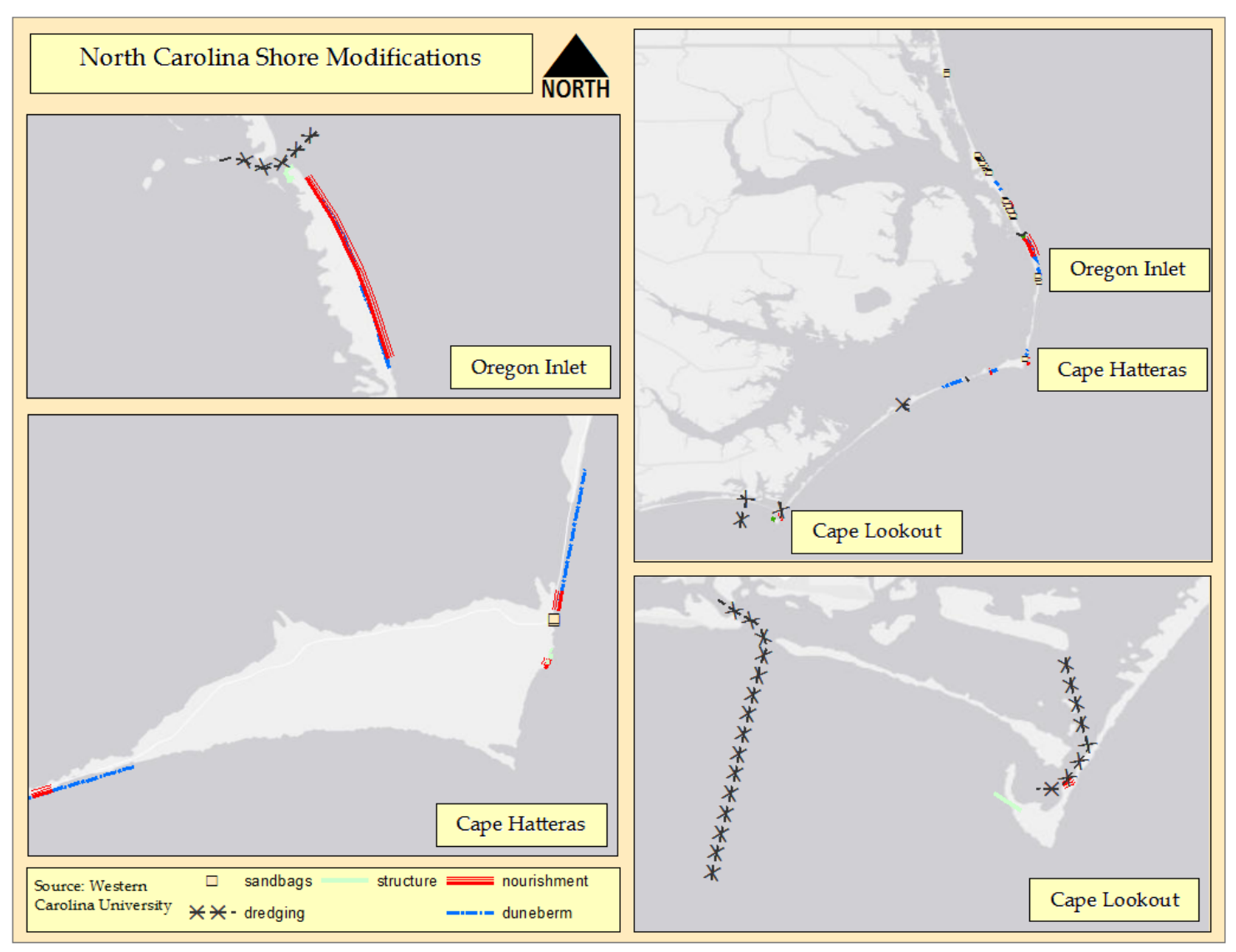

Figure 1: Location of Modifications

Locations where extensive coastal management projects have taken place.

Modifications of this type expand to cover the majority of the North Carolina coastline.

Top Right: Overview of study area and modifications. Bottom left corner: Cape Hatteras

Top left corner: Pea Island to Oregon Inlet. Bottom right corner: Cape Lookout. 


\subsection{LITERATURE REVIEW}

\subsection{Barrier Island Migration}

Barrier Island migration is a naturally occurring process, accomplished by overwash and inlet breaching processes (Leatherman, 1979; Riggs et al., 2009; and Donnelly et al., 2006 and many others) which are driven by storm events. The latter is thought to contribute more to migration (Pierce, 1969, Godfrey and Godfrey, 1973, Leatherman, 1979 in Sallenger 2000). Through storm surges driven by powerful winds influenced by bathymetry and tidal timing, water is pushed into the bay areas. When the storm passes over the location, the winds switch direction and the "... water level on one side of the beach barrier exceeds some critical elevation, with duration of higher water also contributing to the breaching potential (Kraus et al., 2002)" and results in the creation of an inlet. Inlet formation can be accomplished by two methods: the water moving over the barrier feature cuts down and channelizes through the sand; or the water percolates through the material and moves the liquefied sediment in a series of large events. These two processes may occur concurrently.

Over a period of time these inlets eventually change to adapt to a planiform morphology that's dependent on: estuarine geometry; tidal prism; longshore sediment transport; wave action; tidal flow; sediment type; configuration of constructed jetties; dredging; width; depth; occurrence of storm events; and many additional factors (Kraus 2003). In microtidal coasts, inlets have a propensity to close if there is no significant input from a river to the lagoon. They also create tidal deltas (ebb and flood) that shoal up over time due to the deposition of sediment moved by the exchange of tides. These deltas 
can result in long routes for water movement, and will cause the inlet to shift perpendicularly along the barrier island. Eventually, a stage will be reached where the inlet becomes hydraulically inefficient and will close. This process of opening, migrating, and closing of inlets results in the movement of materials in a form of flood deltas from one side of the island to the other and ultimately results in movement of the island itself in a net direction (i.e. migration) (Leatherman, 1988).

\subsection{Sea Level Rise}

Sea level rise is an important topic of discussion caused by a number of factors both globally and locally. The proximate causes are thermal expansion of ocean waters, and the melting of glaciers, icecaps, and icesheets (IPCC 2007). In the $20^{\text {th }}$ century, the global rate of sea level rise has been determined to be around 1.4-2.0 mm/yr. (Church and White, 2006). Local sea level rise may vary from this global estimate, and can be more influenced by the movement of the land in the form of glacial rebounding and/or subsidence.

In North Carolina, that rate was 3.0-3.3 mm/a (Kemp et al., 2009), with higher rates found in the northern areas of the state (Zervas 2004). These northern areas have higher rates of subsidence due to being located on the Albemarle Embayment (Riggs et al, 2011). Locations such as Oregon Inlet Marina, Beaufort, and Wilmington were all found to have rates higher than $3 \mathrm{~mm} / \mathrm{yr}$. (Zervas 2004). However, rates determined from on Oregon Inlet and Duck tidal gauges may not be of sufficient duration for long-term assessment. As demonstrated in Douglas (1992), significant variation in acceleration rates exist for gauges less than 40 years in age. The age of these tidal gauges varied, with 
Beaufort beginning in 1953, Oregon Inlet in 1977, Duck in 1978, and Wilmington in 1935. Based on the Duck, North Carolina tidal gauge, projections for 2100 predict a total rise of 0.4 to 1.4 meters (NC CRC 2010).

\subsection{Outer Banks of North Carolina}

When development began on the Outer Banks, barrier island migration was poorly understood (Pilkey 1998), and like many other places along the coast, the increase in population resulted in poor management practices to reduce the hazards associated with it. In an attempt to better manage for future development, a number of studies were performed to assist the state in the creation of setbacks for future construction. The North Carolina Sea Level Rise Assessment Report was one these studies, and was prepared by the North Carolina Resources Commission's Science Panel on Coastal Hazards. Through the use of works by Zervas (2004), Kemp (2009), the IPCC (2007), and many others, the study projected a mean estimate of sea level rise of 1 meter along the state's coast (NC CRC 2010) for the year 2100 .

These projections caused some developers to form a group referred to as the NC20 , which has questioned the report's validity mainly on the basis that the tide gauges did not cover enough time to accurately develop a trend analysis. The main issue NC-20 had with this report is that any policy making made from this study would cause significant increases in insurance rates and possibly diminished property values along the coast. Since the politicization of sea level rise in North Carolina, the state has decided to ban any policy based on SLR assessments for the next four years (Reed, 2012). In order to 
provide further examination of SLR impacts, there is a need to demonstrate in even more detail as to what kind of change can and has occurred.

In North Carolina, a number of studies related to sea level rise have been presented in the past 30 years examining the changes that have occurred along the shore and in the bays. Culver et al., $(2001 ; 2006)$ theorized that in the late Holocene a great collapse of the Outer Banks occurred where large (in number and size) inlets existed intermittently between various barrier islands (Figure 2). Through analysis of planktonic foraminifera obtained from core samples, the presence of organisms normally found in more ocean saline conditions were analyzed for the time period of 4100 to $3700 \mathrm{BP}$ and 1150 to $500 \mathrm{BP}$. The hypothesis described by the authors suggests that the only way this could have occurred was by the destruction of portions of the barrier islands by a number of successively strong hurricanes, which allowed for a larger exchange of water and a movement between the ocean and the sound (Grand Pre et al., 2011). These studies hint at the possibility of collapse of the Outer Banks again due to a large hurricane combined with SLR resulting in islands interspersed with extensive tidal flats (see Figure 2). 


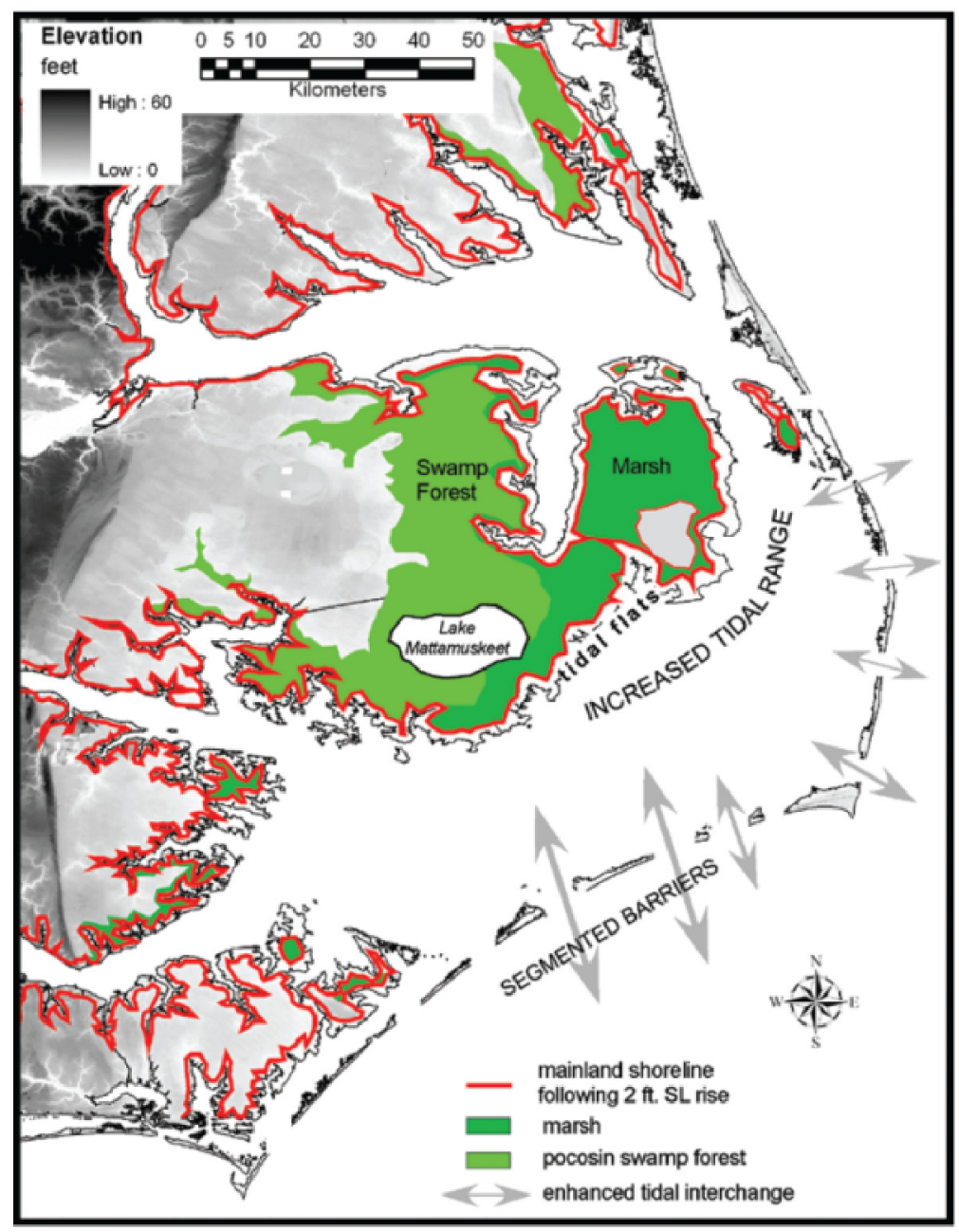

Figure 2: Potential Collapse

Demonstration of possible collapse of the Outer and Core Banks, North Carolina. Source: Mallinson et al., 2008.

\subsection{Topographic survey utilization in literature}

Other studies have looked specifically at more recent changes (i.e. last century) and have used NOS T-sheets to analyze movement of the Outer Banks. Riggs et al. (2009) evaluated the potential for inlets to exist through analyzing barrier widths and elevation. They concluded that Pea Island has been negatively affected by the 
maintenance of Oregon Inlet, that future changes would necessitate the natural movement of Oregon Inlet which would decrease long term infrastructure costs.

Smith et al. (2008) examined barrier island widths at two locations in the Outer Banks, NC. They utilized shoreline data from approximately 1850-1998 to quantify changes that occurred at these locations. One was present at a known erosion hot spot (Avon to Buxton) while the other was located south of Oregon Inlet. It was noted that a portion of Pea Island demonstrated a net gain in main barrier island width (MBIW) as a result of the creation of flood tide deltas. The MBIW represents the largest portions excluding marsh islands present in the bay. Long after these inlets closed, the tidal deltas subsequently were joined with the main portion of the island (which demonstrates migration). The southern portions of Pea Island and the second location of the study in Avon Buxon experienced a net decrease in MBIW.

Everts and Gibson (1983) used NOS T-sheets to find areas of shoreline recession from Cape Henry, VA to Cape Hatteras, NC. They found that along the study area there was a narrowing of barrier island segments by 0.9 meters per year. There have been additional studies analyzing rates of erosion and changes over the past, but these have been more localized, hazard based mapping such as Overton et al. (1999). In their hazard mapping study they found that in Dare County, $50 \%$ of the shore was eroding and $50 \%$ of the shore in Brunswick County was eroding as well. The information was then compared with parcel values to highlight the risk of developing at these locations. Another study by Fenster and Dolan (1993), utilized two T-sheets and aerial photographs to study for a 134 
year period. The research emphasized the difficulty of explaining the driver of erosion or accretion along the ocean shoreline.

\subsection{Summary}

Though the changes of the various Outer Banks sections have been analyzed by several studies and conclusions on barrier island changes have been drawn (Culver et al., 2001, 2006, Everts and Gibson, 1983,Riggs et al., 2009, Riggs et al., 2011, Smith et al., 2008, Overton et al., 1999 and others), a systematic investigation of the changes for the entire barrier island system is lacking. Thus, a complete picture on changes occurring in the Outer Banks in response to sea level rise has not been derived.

These barrier islands have existed for at least the last few thousand years and migrated landward as sea level rose, impacted by waves, storms, and tides. Great storms can segment the Outer Banks by cutting of inlets, however, if left alone, microtidal inlets eventually close resulting in a straightening of the shoreline and rebuilding of dunes by aeolian processes (Leatherman, 1988). Therefore, whether the Outer Banks collapse will occur in the next large hurricane cannot be determined without quantifying the change of the entire system of barrier islands. The objective of this study is to examine how the entire Outer Banks has changed in the past 150 years through quantifying change between historic and modern datasets. 


\subsection{METHODS/DATA}

\subsection{NOS T-Sheets}

The National Ocean Service Topographic Sheets (T-sheets) dated from 1852 to 1878 and modern aerial photographs will be utilized to derive the historical and current shorelines of the Outer Banks. Originally known as topographic surveys, these historic maps are representative of features located on land at a given scale, and, contrary to their name, may not actually show the relief on the ground. Taken within predefined geodetic networks, these maps were painstakingly drawn and executed in a reliable fashion for the time period. They are numbered in sequential order from when they were submitted to Washington which may or may not correlate with the date they were created. They include labeled landforms, descriptive reports (conditions, etc.), and the individuals involved. These surveys can have additional indicators associated with their registry numbers such as; 'Bis' represents sheets that have been because of degradation; and 'a and $\mathrm{b}$ sheets', that are joining surveys in spatial extent. Surveying methods were variable (mostly plane table, alidade, and stadia marks), and were performed during the summer with a few exceptions (Shalowitz and Reed 1962).

Using T-sheets for analyzing trends in change has been well documented and applied in various studies (Riggs, et al., 2009, Zhang et al., 2004, Everts and Gibson, 1983, Crowell et al., 1999 Leatherman and Anders 1999, Leatherman and Eskandary, 1999 and others). As they are quite old, questions about their accuracy have been extensively studied (Shalowitz and Reed, 1962, Crowell et al., 1991, and Crowell et al., 1993, Daniels and Huxford 2001 and others) and the error present is countered by a large 
extension of the temporal study period. The longer in time the dataset extends, the more accurate it will be for trend analysis. These valuable datasets were obtained from the NOAA Historical Shoreline Survey Viewer unreferenced and uncorrected format (http://specialprojects.nos.noaa.gov/tools/shorelinesurvey.html).

In order to maintain data quality, the georeferencing and digitizing processes of the scanned imagery and NOS T-sheets must maintain a clear set of topology in order to reduce error. During the georeferencing process, the T-sheets were rectified using a series of methods as demonstrated in Crowell et al., (1991), Shalowitz and Reed (1962), and a contractors manual created by the NOAA Coastal Services Center.

The varied map projections, the benchmarks present, and the years available (1852-1874) can make it difficult to determine which T-Sheet is the most appropriate for depicting historical shoreline positions. Some have been updated to NAD 1927, which offers the best choice as they would be referenced to a modern datum. However, the benchmarks present for this datum sometimes might not provide enough control points. In this case, utilizing older projection lines is better suited. Maps that were less detailed but were covering the same spatial extent of another T-sheet from a different year were excluded. 


\subsection{Georeferencing}

Georeferencing a T-Sheet to North American Datum 1927, U.S. Standard, or North American Datum (pre-1927) involved setting four bounding coordinates for each map. Inside these bounding points controls were created that cover each portion of land and waters one minute latitude and longitude from the shore. Usually, 20+ control points were designated for each T-sheet. The coordinates were located using written numbers on the edges of the sheets and manually entered into the GIS software. Using common features on the land would have been the preferred choice, but there were few or no permanent structures present at that time that remain today. RMS error for the entire project was low (usually around 0.07 meters) (see Figure 3 for visual aid (NOAA CSC)). $1^{\text {st }}$ order polynomial transformation was chosen in order to minimize distortion and rotation of the maps.

For T-Sheets utilizing coordinate systems older than NAD 1927, shifts were calculated using known triangulation stations to bring them current (NAD1983). The minimum required number of stations is 4 , which a few T-sheets failed to meet (mostly those based on the Bessel Spheroid). These surveys were excluded from the study. The necessary information to calculate these shifts were provided in the form of bounding coordinates along with the maps' datum and were completed with assistance from the National Geodetic Survey (refer to Table 1). 


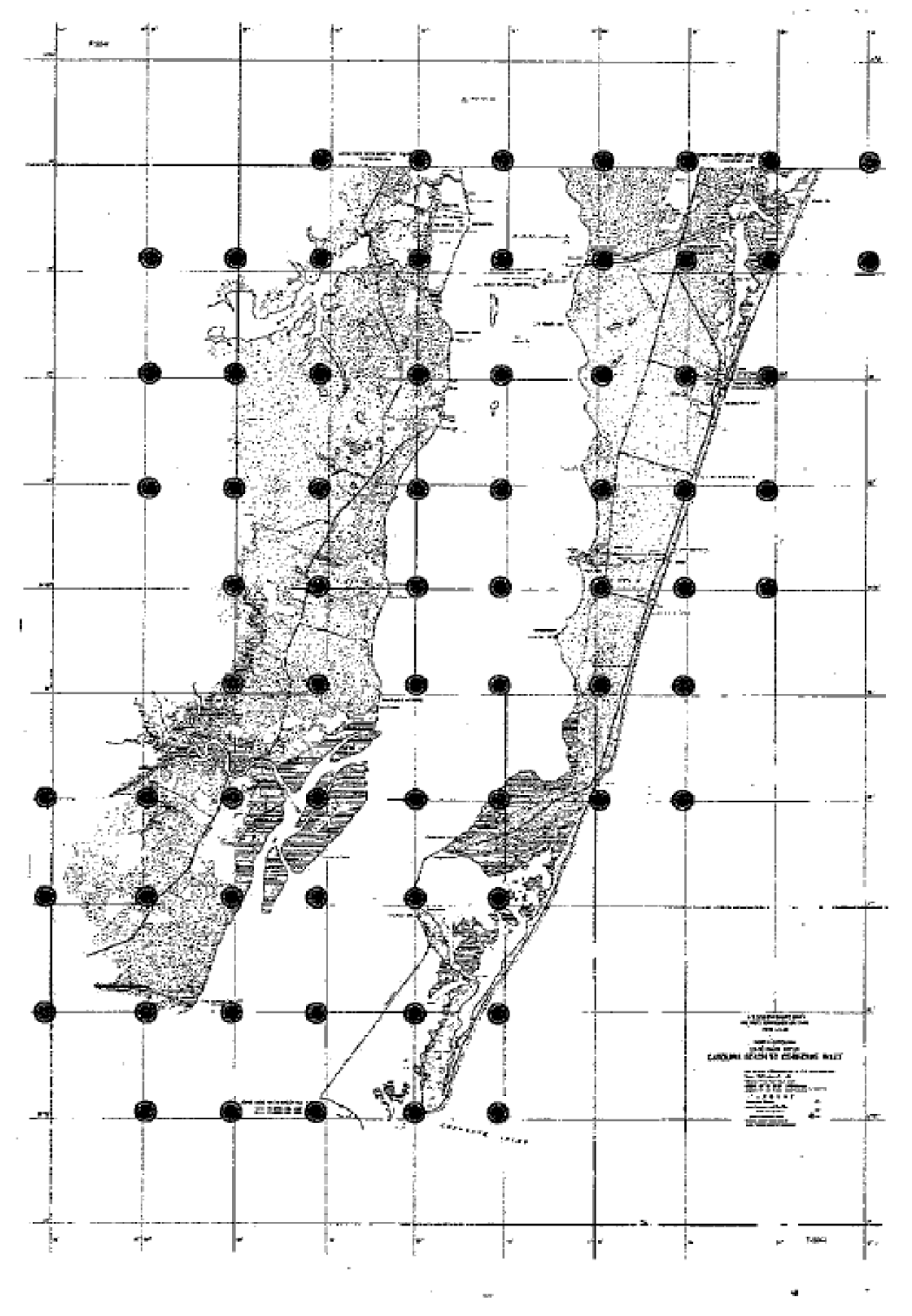

\section{Figure 3: Transect Placement}

Placement demonstration of control points. The author extended the placement of control points to include four bounding locations for each topographic survey. The placement was directed towards the middle portion of the intersecting longitudinal and latitudinal lines. 


\begin{tabular}{|c|c|c|c|c|c|c|}
\hline T-SHEET \# & $\begin{array}{c}\text { Shift } \\
\text { Latitude } \\
\text { Seconds }\end{array}$ & $\begin{array}{c}\text { Distance } \\
(\mathrm{m})\end{array}$ & Std Dev $(\mathrm{m})$ & $\begin{array}{l}\text { Shift } \\
\text { Longitue } \\
\text { Seconds }\end{array}$ & $\begin{array}{c}\text { Distance } \\
\text { (m) }\end{array}$ & Std Dev $(\mathrm{m})$ \\
\hline $\mathrm{T}-315$ & 0.111 & 3.41 & 0.11 & -0.657 & -16.88 & 0.26 \\
\hline $\mathrm{T}-381$ & 0.165 & 5.08 & 0.86 & -1.091 & -27.31 & 0.64 \\
\hline $\mathrm{T}-416$ & 0.110 & 3.37 & 0.08 & -0.649 & -16.66 & 0.08 \\
\hline $\mathrm{T}-438$ & 0.111 & 3.43 & 0.24 & -0.653 & -16.78 & 0.29 \\
\hline T-565 & 0.300 & 9.24 & 0.36 & -0.631 & -16.21 & 0.13 \\
\hline T-617 & 0.378 & 11.65 & 0.19 & -0.68 & -17.28 & 0.12 \\
\hline $\mathrm{T}-618$ & 0.398 & 12.27 & 0.13 & -0.689 & -17.65 & 0.09 \\
\hline $\mathrm{T}-619$ & 0.409 & 12.62 & 0.69 & -0.693 & -17.76 & 0.27 \\
\hline T-620 & 0.440 & 13.55 & 0.20 & -0.707 & -18.12 & 0.08 \\
\hline $\mathrm{T}-621$ & 0.449 & 13.85 & 0.07 & -0.715 & -18.34 & 0.06 \\
\hline T-709 & 0.456 & 14.05 & 0.14 & -0.722 & -18.53 & 0.19 \\
\hline $\mathrm{T}-711$ & 0.334 & 10.3 & 0.38 & -0.652 & -16.75 & 0.18 \\
\hline T-1016 & 0.198 & 6.11 & 0.09 & -0.967 & -24.52 & 0.45 \\
\hline T-1017 & 0.124 & 3.82 & 0.19 & -0.648 & -16.42 & 0.30 \\
\hline T-1020 & 0.184 & 5.67 & 0.66 & -0.838 & -21.29 & 1.72 \\
\hline $\mathrm{T}-1110$ & 0.122 & 3.77 & 0.05 & -0.631 & -16.05 & 0.05 \\
\hline T-1215 & 0.16 & 4.94 & 0.26 & -0.622 & -15.97 & 0.15 \\
\hline T-1291 & 0.195 & 6.01 & 0.59 & -0.600 & -15.40 & 0.34 \\
\hline $\mathrm{T}-292$ & 4.65 & 143.3 & 3.5 & 17.67 & 442.6 & 1.6 \\
\hline $\mathrm{T}-354$ & 4.65 & 143.3 & 3.5 & 17.67 & 442.6 & 1.6 \\
\hline $\mathrm{T}-674$ & 0.451 & 13.88 & 0.06 & -0.722 & -18.55 & 0.02 \\
\hline T-708 & 0.434 & 13.39 & 0.31 & -0.724 & -16.41 & 0.32 \\
\hline T-790 & 0.456 & 14.05 & 0.14 & -0.722 & -18.53 & 0.19 \\
\hline $\mathrm{T}-792$ & 0.222 & 6.84 & 0.52 & -1.056 & -26.71 & 1.00 \\
\hline
\end{tabular}

Source: National Geodetic Survey: Chief Geodetic Surveyor Dave Doyle

\section{Table 1: Calculated Transformations}

Calculated shifts for transformation to North American Datum 1983. These were completed with the assistance of the National Geodetic Survey (NGS) (Dave Doyle, Personal Communication, 2012). 


\subsection{Digitization Process}

After the T-sheets were referenced. they were then digitized using recognizable features as described in a legend provided by Shalowitz and Reed (1962), and descriptions on the T-sheets themselves (Figure 4).

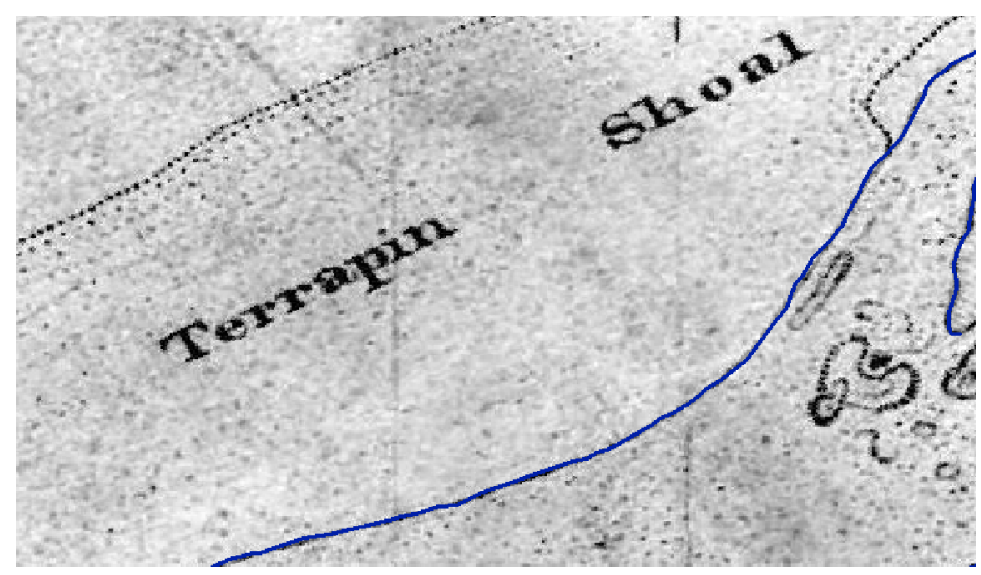

Figure 4: Demonstration of the digitization process

Features that are considered to be partially covered by water the majority of time (i.e. shoals) were excluded as land features. Where confusion existed as to what feature was present on a particular portion of the T-sheet, digitization was omitted. 


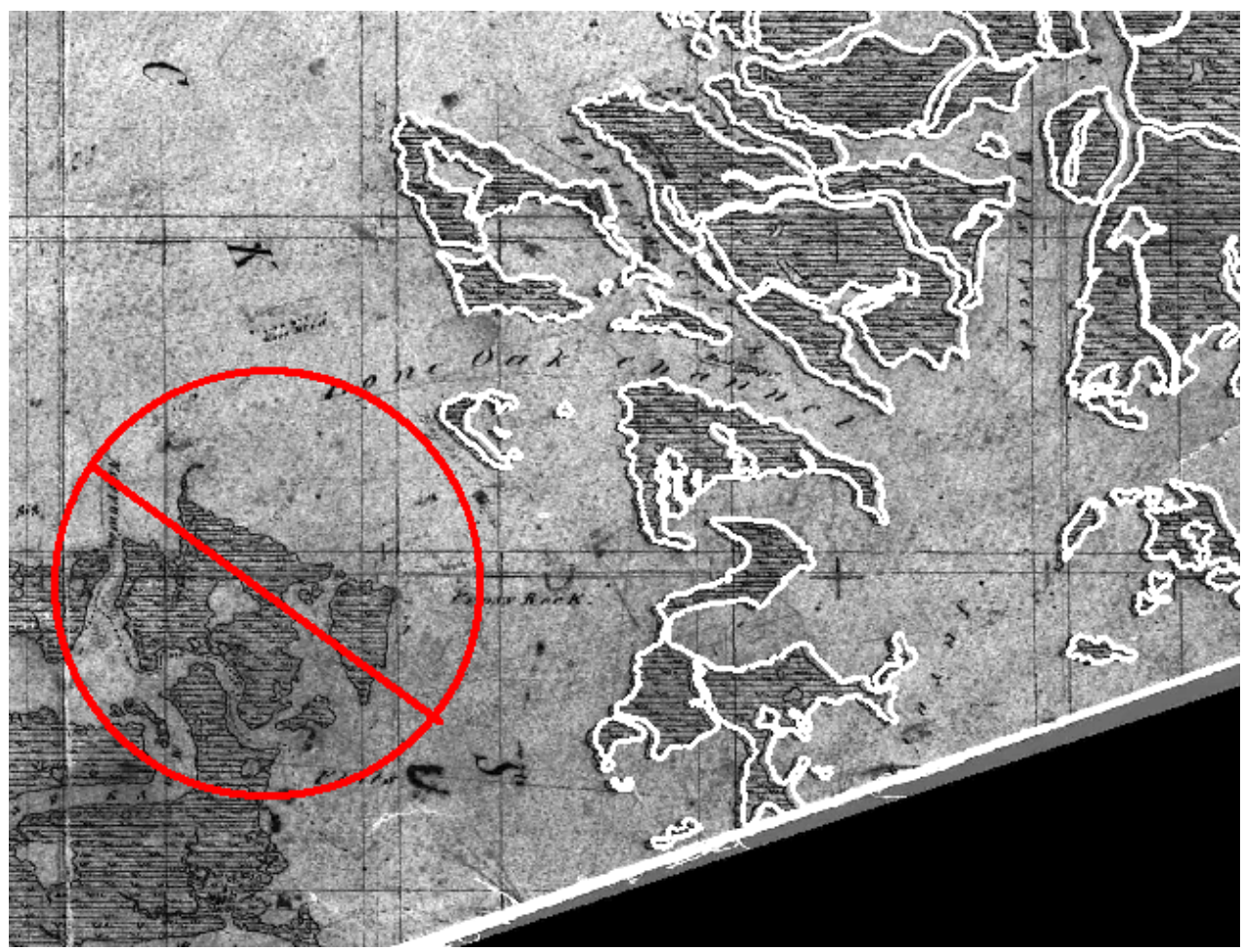

\section{Figure 5: Example of marsh island exclusion in T-sheet 381(2)}

Islands existing in the bay that were more likely associated with another feature than the barrier island were excluded from the study. The white lines represent the back barrier islands, while the red circle is the islands that were not included.

Marsh islands that did not seem to be closely associated with the main barrier island segment were excluded (see Figure 5). The scale at which the digitization was performed varied, as the scale on the maps themselves varied. Significant overlap occurred between a number of the sheets, which was anticipated. The features chosen that overlapped but did not line up was dependent on the T-sheet that best matched the bounding sheets in year. Another common issue was the presence of poorly drawn features. These features often corresponded with like features on the adjacent T-sheet. It was assumed that they merely represented a rough estimate of the location of this feature 
as they included simple lines, shapes and no infilling that matches the legend in Shalowitz and Reed (1962). As a result, the same feature that was better depicted on the overlapping tile was chosen for digitization. In instances where the features were determined to be similarly detailed but did not line up correctly, a midpoint was established to shift the sheets accordingly.

\subsection{DOQ's}

Digital Ortho Quadrangles (DOQ's) collected for the year 2004 at 7.5 minute intervals with a resolution of 1-3 meters were obtained from the USGS National Map Viewer (http://nationalmap.gov/viewer.html). Additional imagery from 2007 to 2009 was found to be of a better resolution ( 0.3 meters or 1 foot) but with more restricted coverage. The sources for these images depended on their location, some being from the North Carolina DOT, Dare County, and the National Agriculture Imagery Program (NAIP). Methods were established to assist in choosing the most appropriate image (and date) based on resolution, presence of features such as high water lines, and whether those features were distinguishable enough to digitize. For imagery to be used from the same year, it was preferred that the tiles cover both the backside and oceanside of the barrier island. Next, the image with the highest resolution was chosen. If it did not present the high water line clearly, the older and less resolute tiles were used. Finally, if at this step features were still not discernible, digitized shorelines were obtained from North Carolina Division of Coastal Management. These images were chosen in a manner that best corresponded to the dates of the mosaics from the USGS. 


\subsection{DOQ Digitization}

The datasets were already georeferenced, but a few will require spatial adjustment to more accurately overlap the T-sheets. Digitization followed procedures utilizing commonly accepted methods. For instance, the high water line was created using the difference in coloration on the beach at a uniform scale. If the high water line was hard to distinguish, debris lines were used as a substitute. Although not as accurate as GPS surveys, the high water line is sufficient for utilization as a shoreline indicator (Pajak and Leatherman, 2002). On the back barrier side, digitizing followed the edge of the marsh line, ignoring darkly covered flats extending from the grass into the water. Much like the highwater line, the darker features likely were submerged on a regular basis. Permanent structures that extended into the water were included, but features such as wooden docks were not.

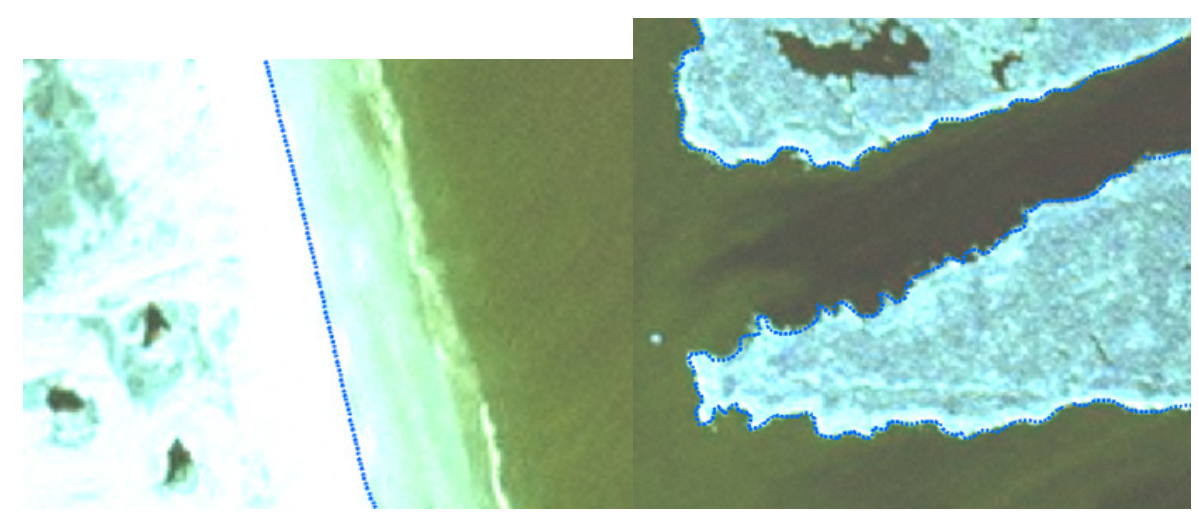

\section{Figure 6: DOQ digitization example}

Notice the clear distinction in color in the first image that allows determination of the high water line. 
As with the T-sheets, islands that were too distant or closer to the mainland than the main barrier island were excluded from the digitization process. Finally, individual feature classes were created for each DOQ or tile of imagery, and will be joined based on the spatial location and extent of the T-sheets. Where uncertainties existed in the modern imagery, additional data sources were used to fill the gaps. These datasets were obtained from the North Carolina Department of Environment and Natural Resources: Division of Coastal Management (http://www.nccoastalmanagement.net/Maps/chdownload.htm).

\subsection{Tide Gauges}

Tide gauge data from NOAA (http://tidesandcurrents.noaa.gov/) were utilized as well. The tidal gauges contain valuable information on localized SLR trends over the course of the study period. The dataset has been corrected to eliminate seasonal variability and short term trends. Issues about the length of tide gauge records have been addressed (North Carolina Sea Level Rise Assessment Report 2010, Zervas 2004, and others).

\begin{tabular}{|l|r|r|}
\hline Location & \multicolumn{1}{|l|}{ Year } & SLR $(\mathrm{mm}) / \mathrm{yr}$ \\
\hline Beaufort & 1953 & 2.57 \\
\hline Oregon Inlet & 1977 & 2.82 \\
\hline Duck & 1978 & 4.59 \\
\hline Wilmington & 1935 & 2.07 \\
\hline
\end{tabular}

Source: NOAA tidesandcurrents.noaa.gov/sltrends.html

Table 2: Location of tide gauges, dates they were installed, and derived SLR trends 


\subsection{Pre Processing}

After the initial stages of data creation, the barrier segments were then run through a rigorous series of steps in order to ensure proper procedures were followed for later data manipulation. Topology was attributed to the data series for both time series in order to locate incorrect lines that are referred to as dangles and segments whose end nodes did not connect. Topology involved both an automated process of setting tolerances within a certain number of meters (determined by a visual evaluation of errors to determine a common distance) for removing dangles and connecting lines and manual operations of deletion and addition. Topology processes not only ensured that barrier segments were fully connected, but also that features were properly digitized. If the spacing between two lines was significant, imagery was used as a reference in order to ensure accurate placement.

\subsection{Transects}

Utilizing a toolset provided freely available online through the United States Geological Survey, called the Digital Shoreline Analysis System (DSAS), transects were created covering all locations involved in this study. The four different study locations were based on geographic separation, most often by inlets or type of barrier island. Currently, these study areas include (from south to north); Cape Lookout, Core Banks, Ocracoke, and Cape Hatteras. These transects were based off a series of baselines previously created by the author. These baselines were developed in a manner that coincides with the shape of the shoreline for the segment to be studied, and were separate features in order to ensure proper distance spacing was maintained for each transect 
section. The distance between the transect lines was set at 50 meters. The total length of each transect was set to 50,000 meters, in order to ensure with certainty that all features (including back barrier islands) were contained.

\subsection{Final Procedures}

Once this step was finished, transects were edited as closed segment polylines and converted into polygons. These closed transects were numbered in an ascending order, and were clipped with the barrier features for the historic and modern datasets. This information was verified to ensure that different features that fell within the same transect identification number were correctly represented in each dataset.

Intersections were then performed to combine the two datasets with the same transects covering the same spatial extent. The result was an attribute table that contained all the distance and area measures associated with the transect features post intersect. If a dataset was missing a particular shoreline that prevented closure and conversion into polygon features, it was boxed off in a manner that allowed for later recognition and removal.

The process continued with combining the two datasets from the different years. This was completed by a join function based on the transect identification numbers, which were a common field found in both files. Summarize functions were performed to combine alike transect ID's (which were present in different locations in some locations, as in found on the main barrier segment and back barrier island), with the intent of gaining statistical information on length and area. This information was then tabulated for 
each study location, with emphasis on mean, standard deviation, total area, total change, minimum, and maximum values for the transects.

The Digital Shoreline Analysis System was also adapted for a key metric in this research. While it is used strictly for the measurement between two shorelines, its application to the mean centerlines for the study areas was highly beneficial. This was completed by merging the two years, and using the net shoreline movement function. This takes into consideration the date of the shoreline, returning negative or positive values by furthest distance between the two lines. These mean centerlines were constructed using a mean center function of the transects. Since the transects corresponded in their numbering, a weight function was applied to consider the total area of transects that shared the same number (i.e. ID 128 includes 3 portions; one from the main barrier segment, a two portions of separate back barrier islands). This ensured that the positioning of the mean center did not only consider the relative distance between the multipart transects.

\subsection{Construction of visual aids}

The next step involved classifying and visualizing the amount of change that occurred. With the joined features found in the same file, 10 classes were created for each study area. These were determined by using the natural breaks (or Jenks) classification. Alike color scales were chosen to ensure easy comparison, with transects representing a dark green color demonstrating the highest class of increase in area, yellow showing little to no change, and dark red showing the highest decrease in total area. 
Additional visual analysis involved the construction of mean center lines for the segments. This line represents the center point for each transect, including the back barrier island portions. As a result, the mean center line can be located in a water body. This is a unique application to this type of study and will provide valuable insight to how the locations of the barrier islands has changed overtime. For instance, if the mean center line for the historic dataset is located further seaward, this might show that as a whole, the island has properties of landward, directional movement.

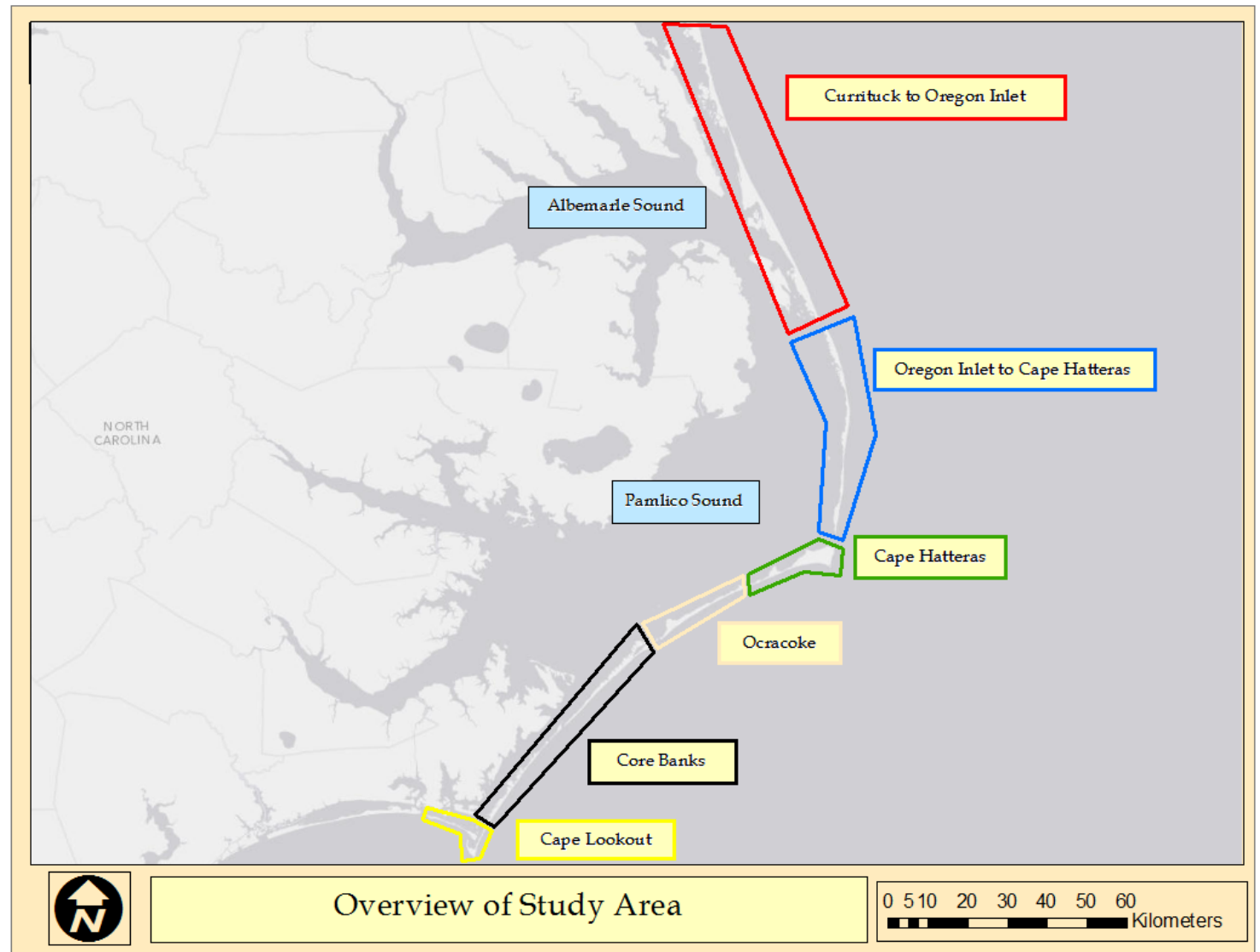

\section{Figure 7: Overview of Study Area}

Locations of study areas. The breaks between the six different zones were determined by natural features (i.e. inlets). 


\subsection{RESULTS}

\subsection{Oregon Inlet to Currituck Sound}

The northern portion of the Outer Banks stretches from the Virginia border down to the northern end of Oregon Inlet. This section of the study area is dominated by large dunes around Kitty Hawk and Kill Devil Hills, with highly dynamic portions influenced by Oregon Inlet to the south . Northern portions are dominated by the Albemarle

Embayment, and experience subsidence as previously discussed. This portion is also the most inhabited area of the Outer Banks, and as a result has seen the most modifications. 


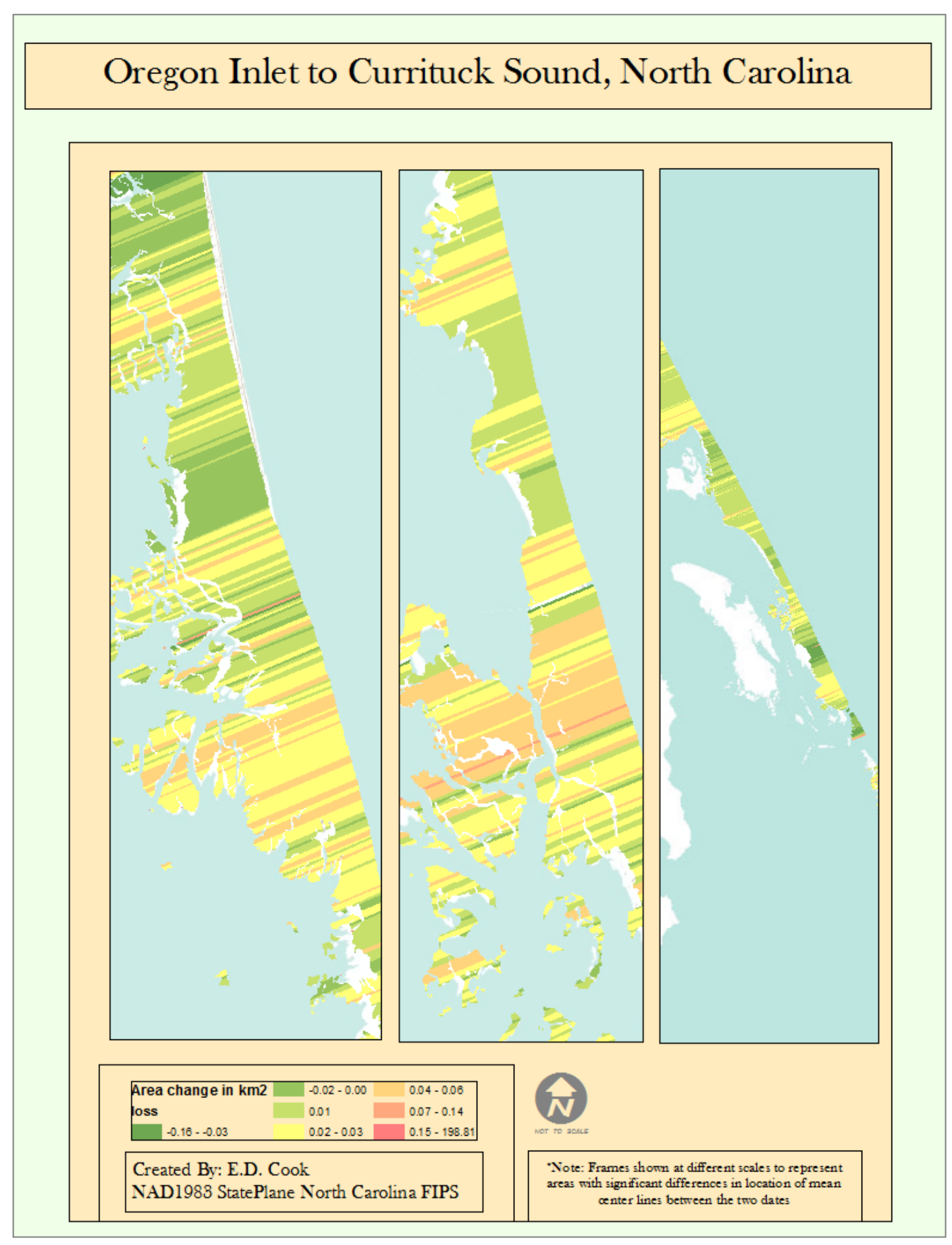

Figure 8: Transects, Oregon Inlet to Currituck 
Visual Analysis of portions of barrier segments from the Virginia border south to Oregon Inlet. Colored closed transects represent the historic location of the barrier segments. Note the almost uniform difference in size between the historic data and the modern barrier position (represented in white).

Closed Transects running through the more northern sections are wide and complex and contain large numbers of back barrier marsh islands. These islands have experienced significant decrease in size but little change in directional movement. Smaller marsh islands found in the bay have disappeared completely, while others have merely shrunk due to subsidence and erosion. Based on visual inspection, the larger islands are becoming more segmented, with an increased number of creeks cutting through.

The barrier bay shoreline is almost uniform in its movement, with a general eastward movement. Portions that are narrower on the main barrier island are the locations where the estuarine shoreline movement is more severe. This may be due to the disallowance of these segments to progress in a more natural environment. On the other hand the ocean shoreline position has not been uniform in its movement. Northern transects show accretion eastward, while southern portions show a trend of erosion on both sides. 


\begin{tabular}{|c|c|c|}
\hline \multicolumn{3}{|c|}{ Change in Area by km2 } \\
\hline Location & Average Change & Total Change \\
\hline Oregon I. to Currituck & -0.01 & -20.96 \\
\hline & Max. Loss by Transect & Max Gain by Transect \\
\cline { 2 - 3 } & -0.23 & 0.16 \\
\hline
\end{tabular}

\begin{tabular}{|c|c|c|}
\hline \multicolumn{3}{|c|}{ Change in Width Meters } \\
\hline Location & Average Change in Meters & Total Change \\
\hline Oregon I. to Currituck & -216.76 & -426369.70 \\
\hline & Max. Decrease & Max Increase \\
\hline & -4639.59 & 1894.52 \\
\hline
\end{tabular}

Table 3: Change in total area, Oregon Inlet to Currituck

Average transect size in square kilometers have not changed much, but there has been a very significant decrease in total area in this segment. Modern segments represent 73.76 percent of the historic land cover. 73.56 percent of transects demonstrated a decrease in total width (including back barrier marsh islands).

\subsection{2: Mean Centerlines}

Analysis of the mean centerlines shows that this section of the study area is mostly uniform in terms of migration. Transects demonstrating significant differences in the positioning of their mean centerlines are the result of the loss of a back barrier marsh island. In the second frame found in Figure 6, this is evident around mid-view.

Positioning of the mean center line in the southern most portions (right frame) varies significantly due to the addition of marsh islands forming on the flood tide delta of Oregon Inlet. 


\begin{tabular}{|c|c|c|}
\hline \multicolumn{3}{|c|}{ Net Mean Center Line Movement } \\
\hline Location & Average Change in Meters & Total Change \\
\hline Oregon I. to Currituck & -93.06 & -183973.01 \\
\hline & Max. Movement Inland & Max Movement Seaward \\
\cline { 2 - 3 } & -2803.93 & 1357.37 \\
\hline
\end{tabular}

Table 4: Difference in mean centerline position Oregon Inlet to Currituck

58.57 percent of transect mean centerlines demonstrated a directional movement towards the bay. 


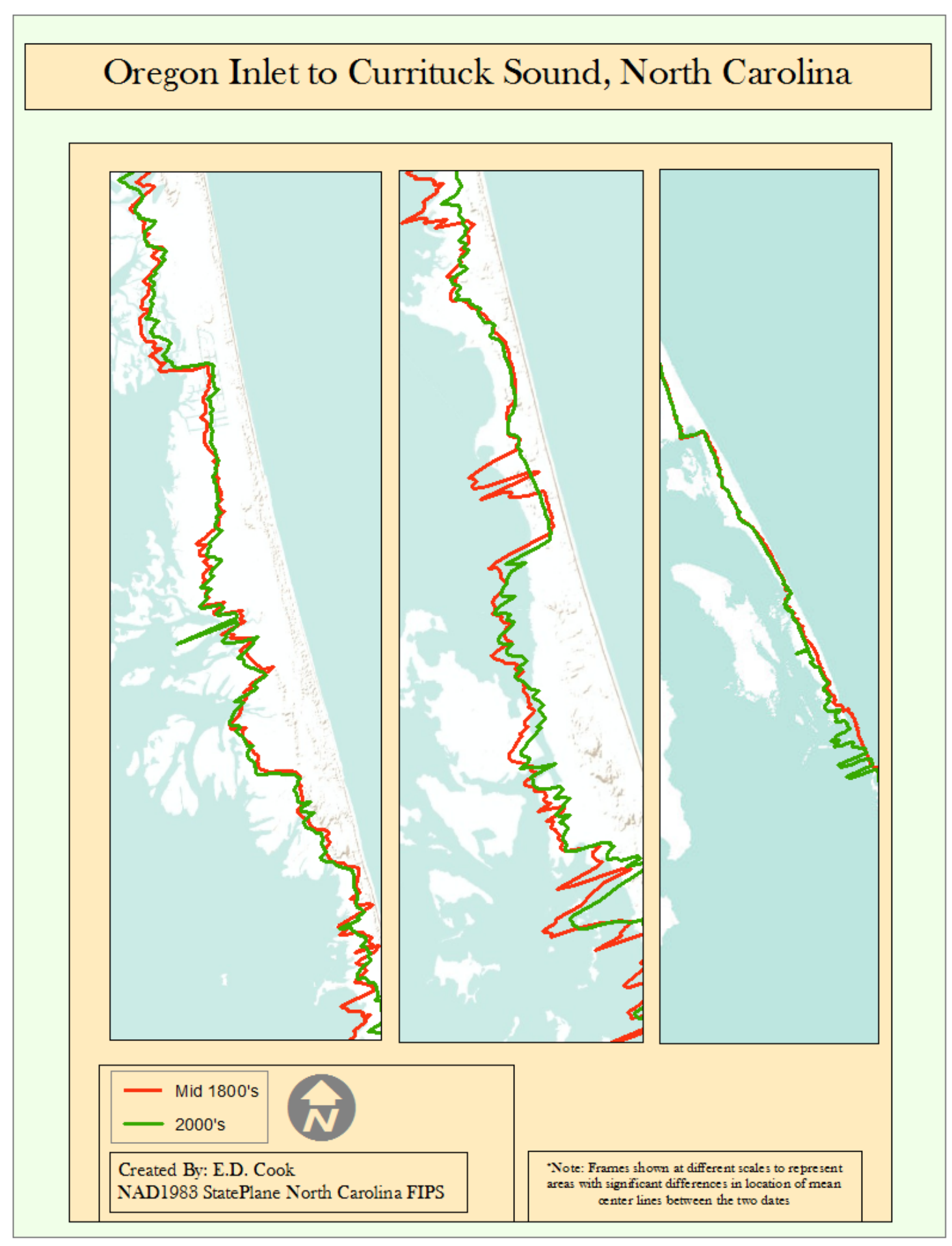

Figure 9: Mean centerline locations, Oregon Inlet to Currituck 


\subsection{Oregon Inlet to Cape Hatteras}

The barrier segments found south of Oregon Inlet are of critical concern and one of the most highly variable locations in the Outer Banks. Pea Island, found directly south of the jetties at Oregon Inlet, has been in a constant state of erosion for an extended period of time. The northern closed transects found in Figure $\mathbf{1 0}$ are highlighted by a deep red color, indicating a significant decrease in area from the historical dataset. The existence of a historic series of inlets is visible in the left frame of the Figure 10, which have been subsequently closed. This clearly demonstrates the process of migration in concurrence of inlets opening and closing. These segments show a large number of back barrier marsh islands that formed, and the movement of the main segment in an inland migratory fashion. 
Even with this significant addition to the barrier segment, the general pattern has been a decrease in total area. Modern islands represent approximately 72 percent of historic segments. Along with the northern portions of Pea Island, the southernmost transects are all decreasing in size. This area has long been susceptible to inlet breeching, but has constantly been reinforced with the maintenance of the dune fields to protect North Carolina Highway 12. Areas near Rodanthe (the bend at the southern portion of the left panel...a known erosion hotspot) have also suffered significant decreases in total area. The passing of the two most recent direct hit hurricanes (Irene and Isabel) have created inlets in close proximity to this location. They were subsequently infilled by the Army Corps of Engineers which has resulted in continued degradation and increased susceptibility to future storms.

\begin{tabular}{|c|c|c|}
\hline \multicolumn{3}{|c|}{ Change in Area by km2 } \\
\hline Location & Average Change & Total Change \\
\hline Oregon I. to C. Hatteras & -0.02 & -16.91 \\
\hline & Max. Loss by Transect & Max Gain by Transect \\
\cline { 2 - 3 } & -0.23 & 0.06 \\
\hline
\end{tabular}

\begin{tabular}{|c|c|c|}
\hline \multicolumn{3}{|c|}{ Change in Width Meters } \\
\hline Location & Average Change in Meters & Total Change \\
\hline Oregon I. to C. Hatteras & $\begin{aligned}-94.82 \\
\end{aligned}$ & -103353.00 \\
\hline & Max. Decrease & Max Increase \\
\hline & -1417.88 & 397.47 \\
\hline
\end{tabular}

\section{Table 5: Change in Area and Width, Oregon Inlet to Cape Hatteras}

78.3 percent of all closed transects decreased in area. 80.37 percent decreased in width. 


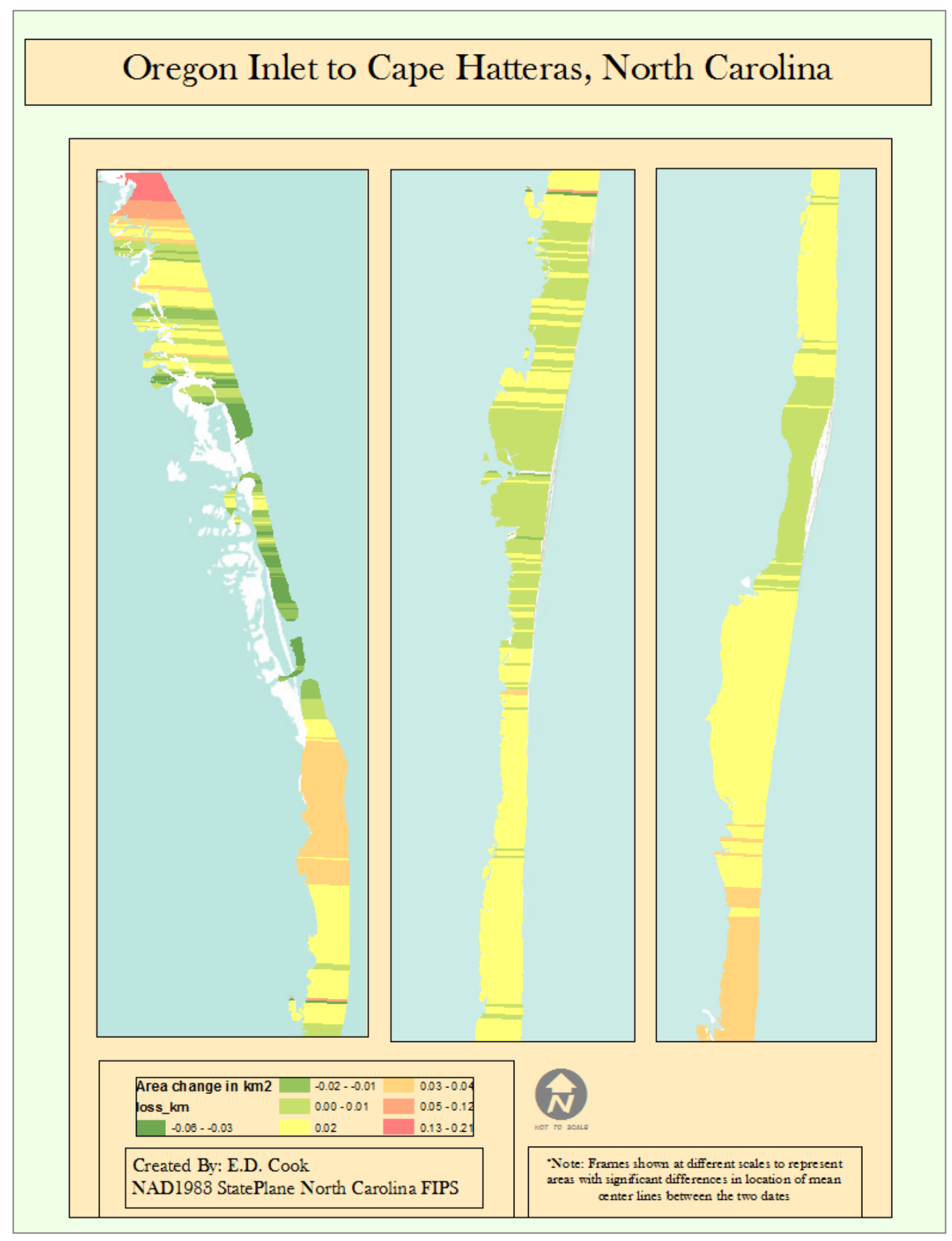

Figure 10: Closed transects, Oregon Inlet to Cape Hatteras 


\subsection{Mean Centerline}

Unlike the study area north of Oregon Inlet, the closed transects located here are highly variable. This represents influence by attempts to stabilize portions north of Hatteras and the higher wave action. Center portions (middle frame of Figure 11) are relatively uniform in their mean center positions, but significant movement can be seen north of Hatteras (right frame). Additional movement in a landward retreating nature is visible south of Oregon Inlet (specifically Pea Island) and at the location of the historic inlets.

\begin{tabular}{|c|c|c|}
\hline \multicolumn{3}{|c|}{ Net Mean Center Line Movement } \\
\hline Location & Average Change in Meters & Total Change \\
\hline Oregon I. to C. Hatteras & -57.28 & -63524.43 \\
\hline & Max. Movement Inland & Max Movement Seaward \\
\hline & -1076.68 & 76.64 \\
\hline
\end{tabular}

\section{Table 6: Centerline change, Oregon Inlet to Cape Hatteras}

Change in position of mean centerlines between historic and modern datasets. Negative values represent movement towards the bay. 49.14 percent of transect mean centerlines had directional movement towards the bay. 


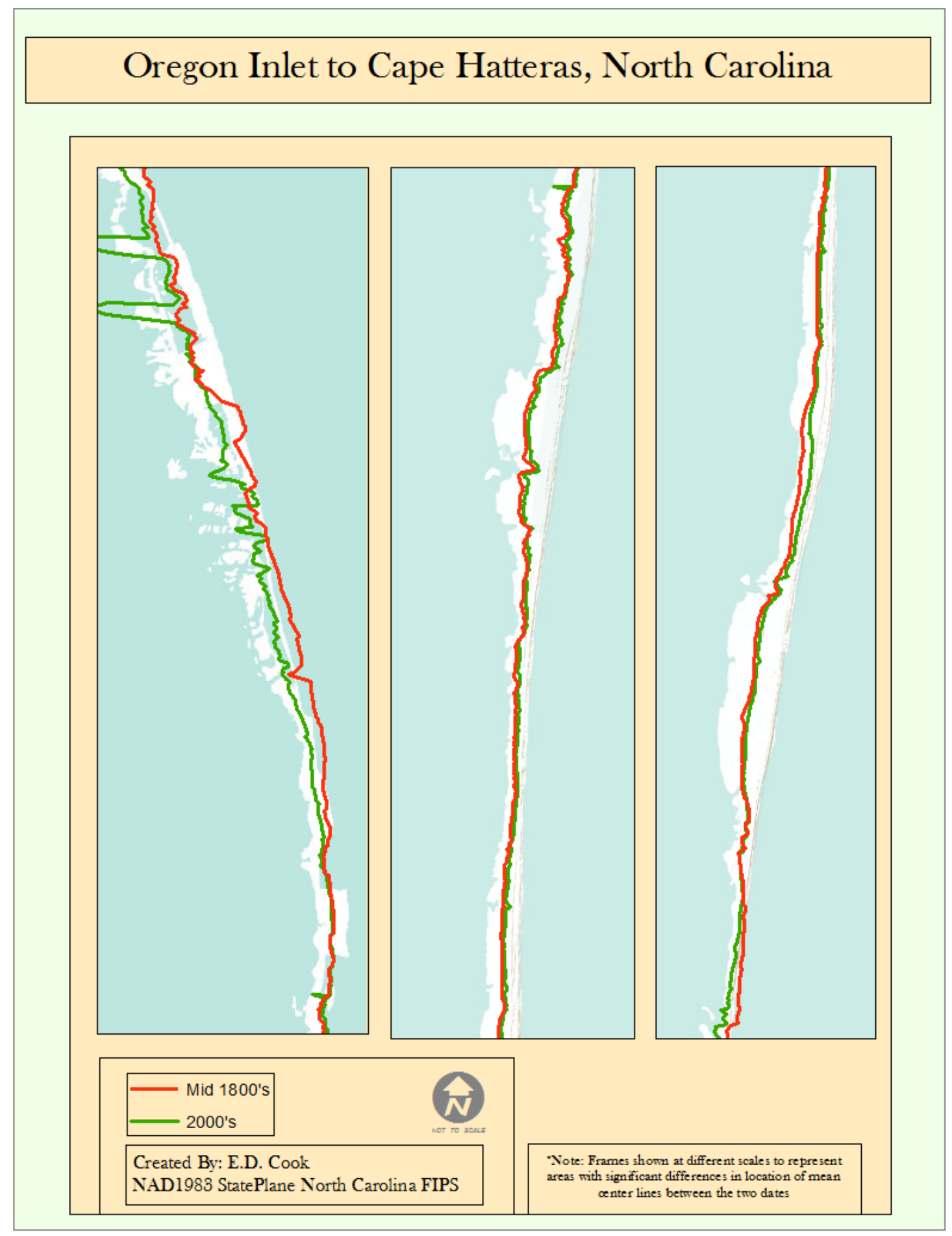

Figure 11: Mean centerline locations, Oregon Inlet to Cape Hatteras 
Mean Centerline locations for transects south of Oregon Inlet and North of Cape Hatteras.

\subsection{Cape Hatteras}

Cape Hatteras is mainly comprised of older sediments, and displays an observed pattern of former beach ridges in the interior of the island, with clear expansion southward and rapid erosion eastward on the northern, east facing ocean shore. Sediment transport is in a southern direction towards Diamond Shoals, which extends off Cape Hatteras. Accretion occurs on the south facing closed transects where wave action is significantly less. Although the size difference between Cape Hatteras and other barrier segments is significant, it is still decreasing in total area with the exception of the southern facing transects. Decreases associated with the movement of Hatteras Inlet to the south-southeast are evidenced by the extension of modern closed transects in this direction. Bayside transects (particularly the deep red portions in the middle of the frame), have suffered from losses due to the construction of canals related to housing development (Figure 13).

\begin{tabular}{|l|r|r|}
\hline \multicolumn{3}{|c|}{ Change in Area by $\mathbf{k m 2}$} \\
\hline Location & Average Change & Total Change \\
\hline Cape Hatteras & -8.64 & -8.64 \\
\hline \multirow{2}{*}{} & Max. Loss by Transect & Max Gain by Transect \\
\cline { 2 - 3 } & 0.00 & -0.25 \\
\hline
\end{tabular}

\begin{tabular}{|l|c|c|}
\hline \multicolumn{3}{|c|}{ Change in Width Meters } \\
\hline Location & Average Change in Meters & \multicolumn{1}{c|}{ Total Change } \\
\hline Cape Hatteras & -32.02 & -13319.84 \\
\hline & Max. Decrease & Max Increase \\
\hline
\end{tabular}

\section{Table 7: Change in total area, Cape Hatteras}


Differences in total area for closed transects segments covering Cape Hatteras.

70.5 percent decreased in area and 69.23 percent decreased in width.

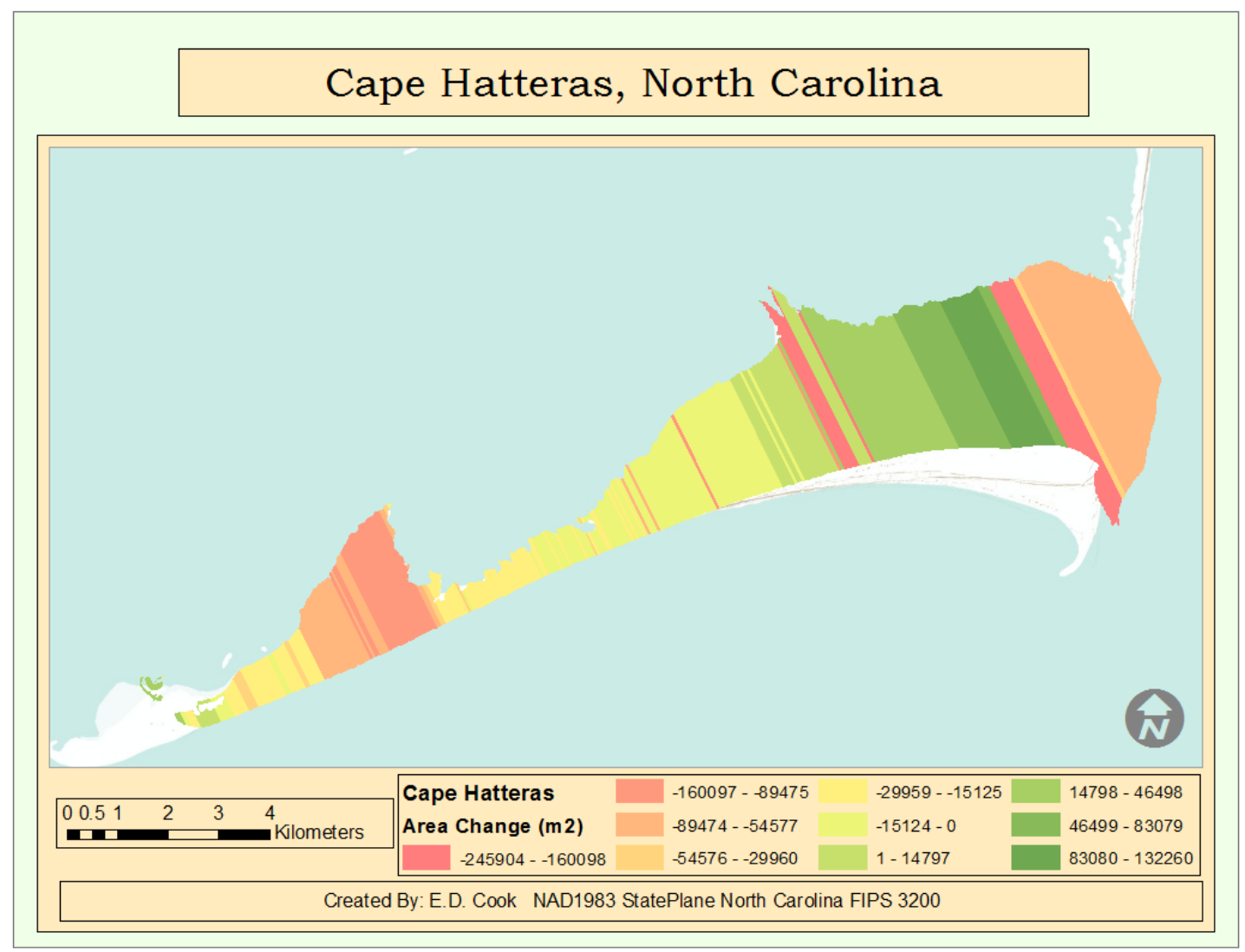

Figure 12: Cape Hatteras Transects 


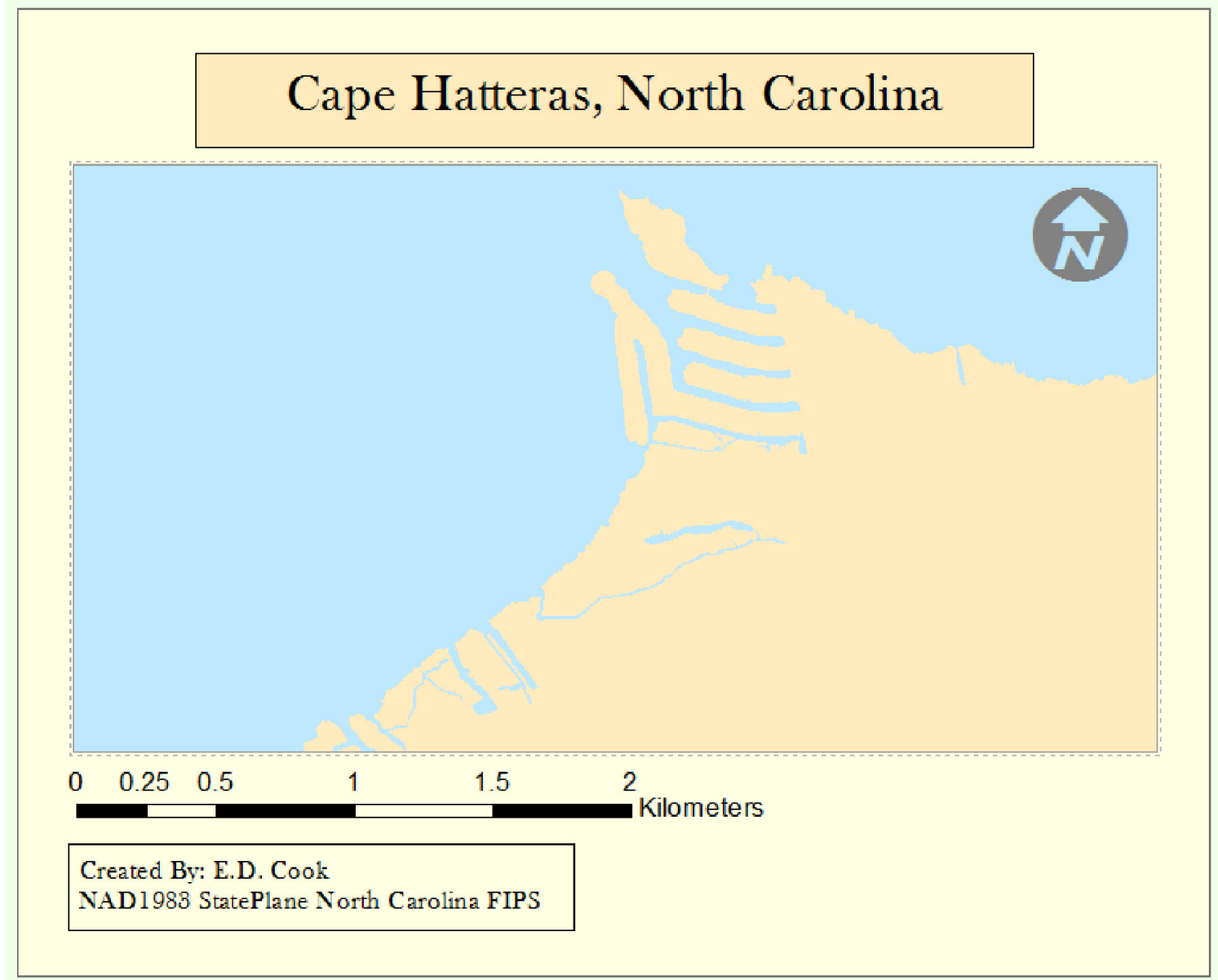

Figure 13: Example of bayside modification to residential areas in Cape Hatteras

\subsection{1: Mean Centerlines}

As Cape Hatteras has one of the most dynamic coastlines in North Carolina, high variability was expected in the location of the mean centerlines. Relative stability is evident in the northern portions near Avon, but the difference increases significantly moving southward. Even with the stabilization attempts and dune fields present, these transects still demonstrate significant movement towards the bay. Movement here likely occurred before the construction of North Carolina Highway 12 and the subsequent attempts to protect it. The aforementioned process of erosion on east facing transects and 
accretion on the south facing transects is evident in the significant shift of centerline positioning in the center of the cape. The southern sections have shown smaller amounts of difference compared to transects located on the main, wider portion of Cape Hatteras. Overall, there has been a slight movement towards the bay.

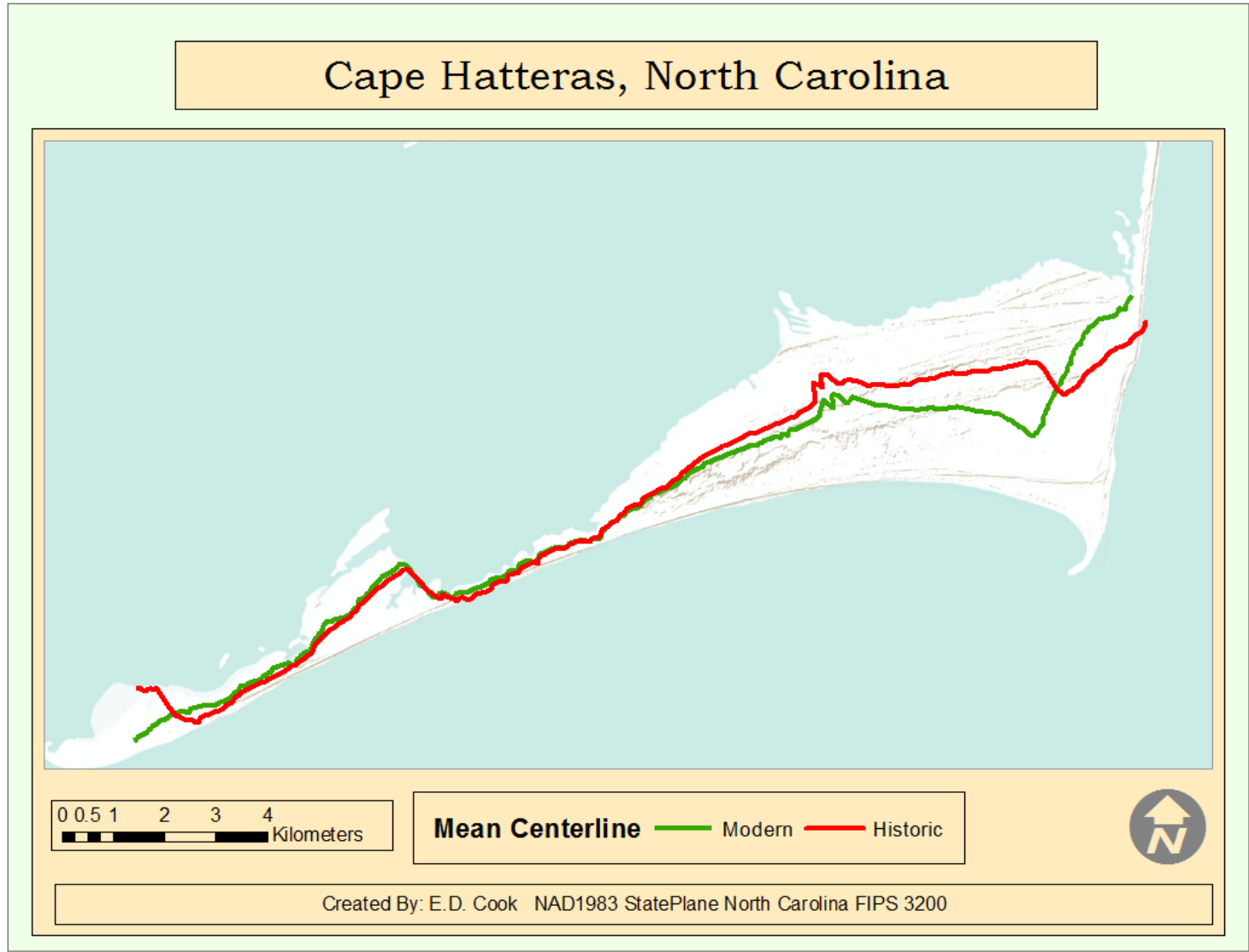

Figure 14: Cape Hatteras Centerline

\begin{tabular}{|c|c|c|}
\hline \multicolumn{3}{|c|}{ Net Mean Center Line Movement } \\
\hline Location & Average Change in Meters & Total Change \\
\hline Cape Hatteras & -12.86 & -2738.18 \\
\hline & Max. Movement Inland & Max Movement Seaward \\
\hline & -88.44 & 237.63 \\
\hline
\end{tabular}

Table 8: Cape Hatteras Mean Centerline Movement

94. 37 percent of transect mean centerlines have moved towards the bay. 


\subsection{Ocracoke Island}

Located in the southern portion of the barrier island strand in North Carolina, this area is largely unpopulated with the exception of the village of Ocracoke on the bayside. Bounded by two inlets, Hatteras to the north and Ocracoke Inlet to the south, it is part of the Cape Hatteras National Seashore. This study area comprised a total of 478 closed transects at 50 meter spacing. The northern portion bounded by Hatteras Inlet has experienced significant migration in an east northeast direction, and has increased significantly in size.

A number of small back barrier islands have disappeared, but extensive sand flats found on the flood tide delta will likely result in further island building from accreting sediments. The middle transects have seen relative stability, with a general pattern of decrease in total area. Southern transects (found in left side of Figure 15) increased both on the bay and ocean sides. Unfortunately, the spatial extent in this location was limited by the exclusion of T-sheet number 622 .

\begin{tabular}{|c|c|c|}
\hline \multicolumn{3}{|c|}{ Change in Area by km2 } \\
\hline Location & Average Change & Total Change \\
\hline Ocracoke Island & 0.00 & -1.08 \\
\hline & Max. Loss by Transect & Max Gain by Transect \\
\hline & -0.05 & 0.08 \\
\hline
\end{tabular}

\begin{tabular}{|c|cr|rr|}
\hline \multicolumn{2}{|c|}{ Change in Width Meters } \\
\hline Location & \multicolumn{2}{|c|}{ Average Change in Meters } & \multicolumn{2}{c|}{ Total Change } \\
\hline Ocracoke & \multicolumn{2}{|c|}{-4.63} & \multicolumn{2}{c|}{ Max Increase } \\
\hline \multirow{2}{*}{ Max. Decrease } & \multicolumn{2}{c|}{431.92} \\
\cline { 2 - 4 }
\end{tabular}

Table 9: Change in area and width, Ocracoke Island 
The total area in $\mathrm{km}^{2}$ from Hatteras Inlet south to Ocracoke Inlet for each time series. Approximately 63 percent of closed transects decreased in area, while 55.8 percent decreased in width.

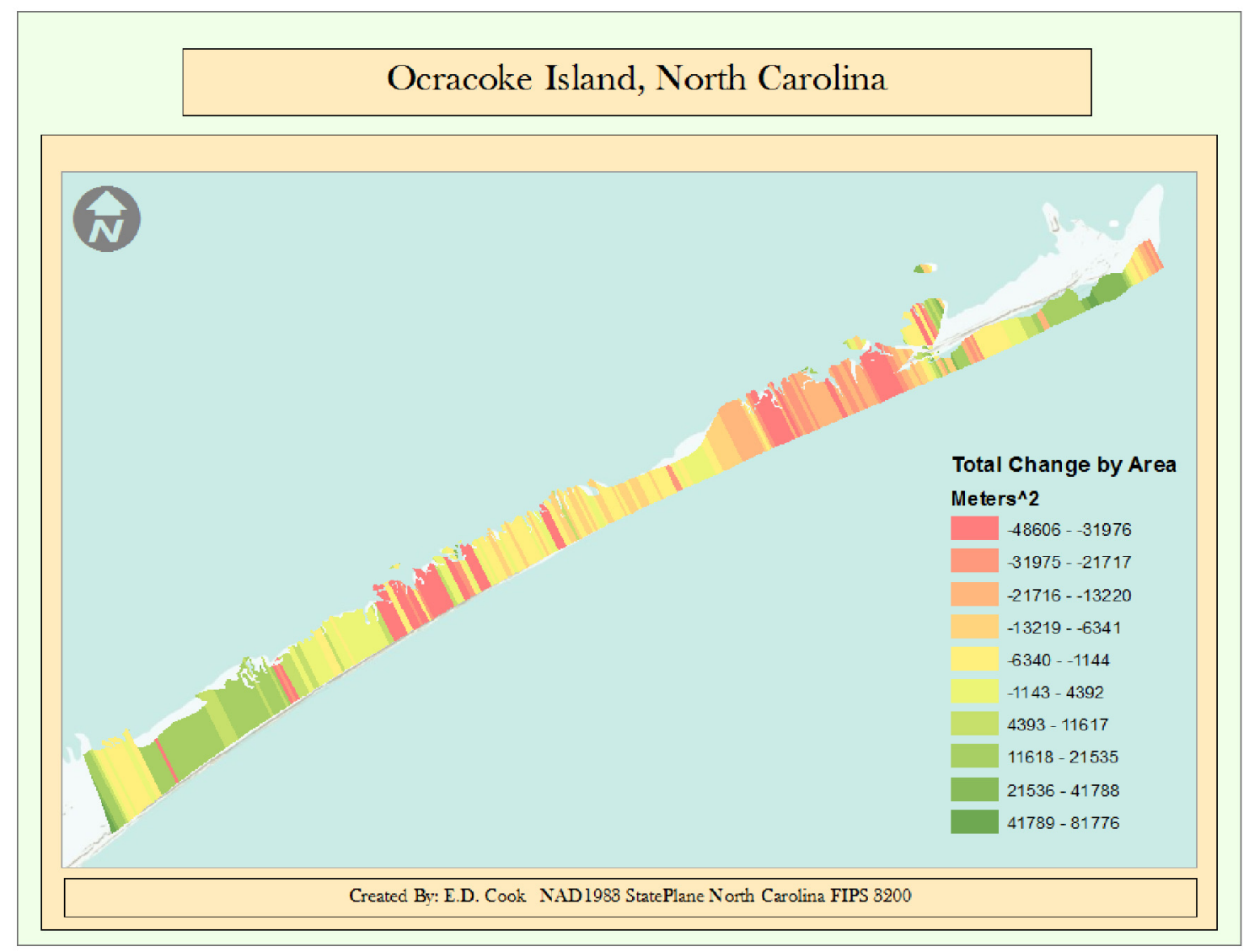

\section{Figure 15: Transects, Ocracoke Island}

The results from the area analysis shows change that is indicative of barrier island response to Hatteras Inlet being maintained. Substantial increase in barrier island areas has occurred in the more southern portions of Ocracoke, while most decreases have been observed in the central portion of the island. With only approximately $2 \mathrm{~km}^{2}$ of loss occurring, Ocracoke Island has shown the least amount of decrease in total area. 


\subsection{Ocracoke Island Mean Centerlines}

The difference in historic and modern centerline reinforces the general trend of stability found in the area analysis of the transects. As in Figure 16, there is little to no change found in the areas located northeast of the village of Ocracoke. This area of relative stability continues north east into the center portions, where there is high variability, due to the disappearance and addition of various smaller back barrier marsh islands. The northernmost transects demonstrate the involvement of inlets in barrier island migration. Although human modifications exist in the form of dredging, the mean centerline difference is the highest in this study segment and has experienced an increase in total area.

\begin{tabular}{|c|c|c|}
\hline \multicolumn{3}{|c|}{ Net Mean Center Line Movement } \\
\hline Location & Average Change in Meters & Total Change \\
\hline Ocracoke & -30.15 & -13115.06 \\
\hline & Max. Movement Inland & Max Movement Seaward \\
\cline { 2 - 3 } & -279.10 & 179.64 \\
\hline
\end{tabular}

\section{Table 10: Centerline change, Ocracoke Island}

Centerline change between modern and historic datasets. The mean change demonstrates on average that the modern centerline is located closer to the bayside than the historic centerline. In total, 35.17 percent of mean centerlines showed directional movement towards the bay. 


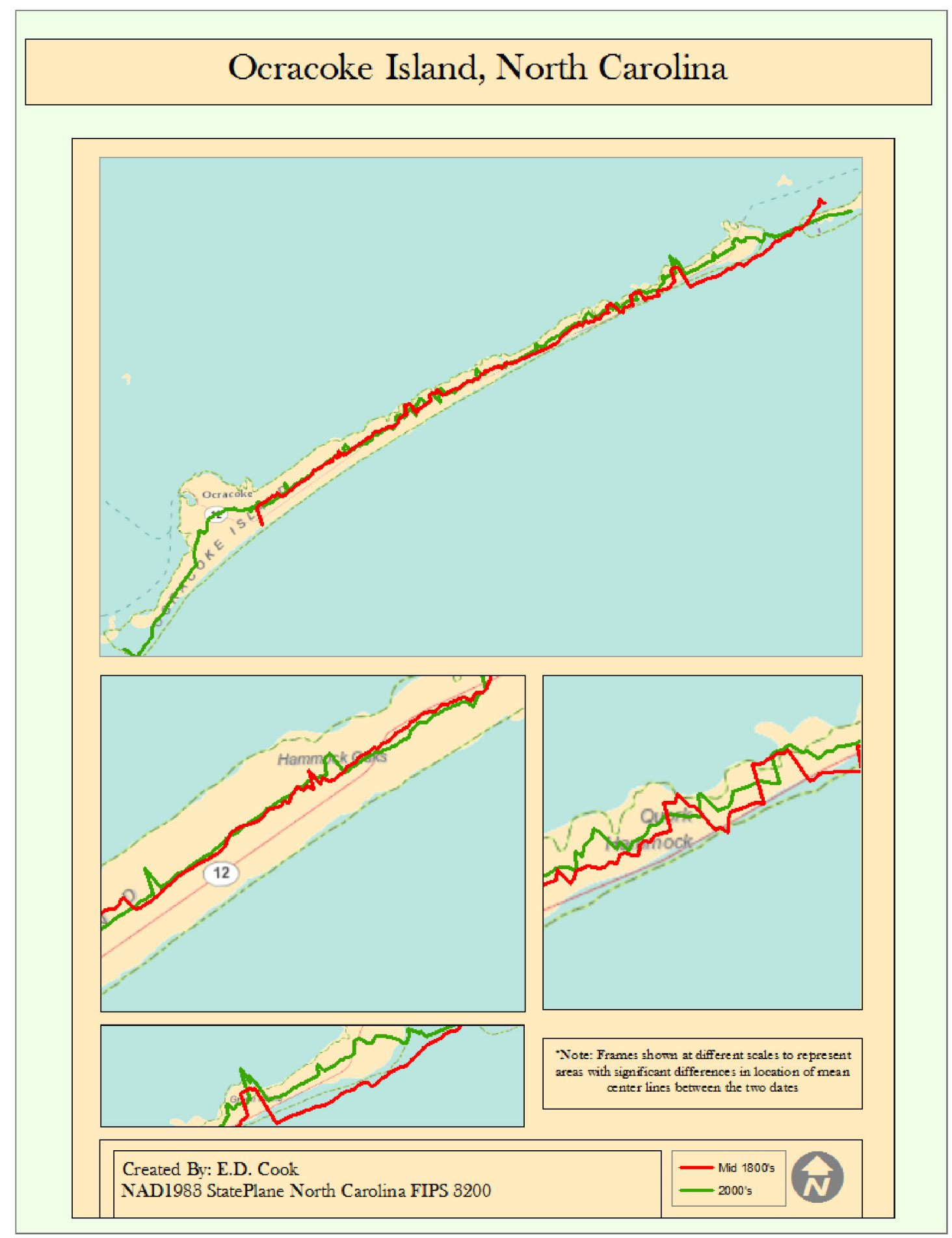

Figure 16: Centerline locations, Ocracoke Island

Mean Center line locations for Ocracoke Island. Red represents historic location 


\subsection{Core Banks}

The Core Banks are found directly north of Cape Lookout. This strip of the island is narrow, and contains a large number of back barrier marsh islands. The northern portion is bordered by Ocracoke Inlet, which extends to Ophelia Inlet, and continues south-southwest till it connects with Cape Lookout. The Core Banks is also a part of the Cape Lookout National Seashore, and is currently uninhabited. The history of inlets along the Core Banks is great, with constant breeching, closing, and migration of Ophelia Inlet and the Drum Inlets. Even with the inlets taken into consideration, the banks themselves are decreasing in area. This occurs mostly in the center portions, in particular the stretch of land from Ophelia to Old Drum Inlet. Historic inlets that have subsequently closed in the southern most closed transects have resulted in the creation of many back barrier marsh islands which is visible in Figure 17 by the dark green strips. Accretion is also occurring on the extreme northern transects bordering Ocracoke Inlet.

In addition to area, the Core Banks has some noticeable changed in width. These values of width represent both the main barrier island width included with the widths of the back barrier marsh islands. The historic dataset has a mean transect width of 2,190 meters, with the widest point being 7,589 meters and the narrowest portion 496 meters. For the modern dataset, the mean barrier island width is 2,204 meters. The maximum width is 7,534 meters wide and the narrowest portion 294 meters. This shows there's been an actual increase in the average width. 


\begin{tabular}{|c|c|c|}
\hline \multicolumn{3}{|c|}{ Change in Width Meters } \\
\hline Location & Average Change in Meters & Total Change \\
\hline Core Banks & -54.87 & -64802.61 \\
\hline & Max. Decrease & Max Increase \\
\hline & -330.18 & 440.27 \\
\hline
\end{tabular}

\begin{tabular}{|c|c|c|}
\hline \multicolumn{3}{|c|}{ Change in Area by km2 } \\
\hline Location & Average Change & Total Change \\
\hline Core Banks & -0.01 & -56.59 \\
\hline & Max. Loss by Transect & Max Gain by Transect \\
\cline { 2 - 3 } & -0.14 & 0.16 \\
\hline
\end{tabular}

\section{Table 11: Summary statistics for Core Banks}

For the Core Banks, 79.17 percent of all closed transects decreased in width.

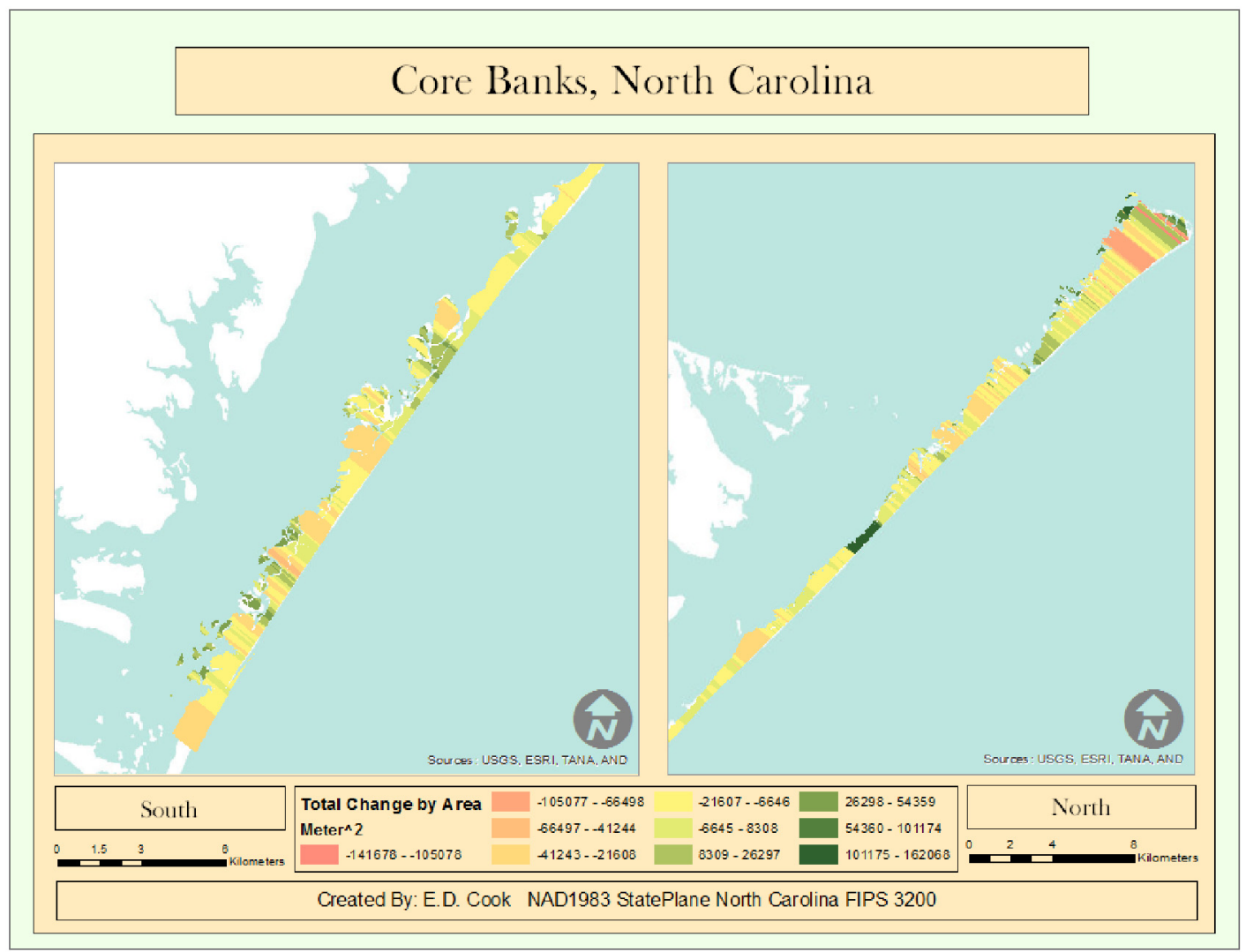

Figure 17: Core Banks transects 
The Core Banks, much like other locations, has shown that the majority of closed transects have reduced in size. Noticeable areas of increase are to the north near Ocracoke Inlet, and in the middle portion of the northern segment.

\subsection{1: Mean Centerlines}

The Core Banks has experienced some regressive migration across a majority of transects. Positioning of the centerlines in the northern portions is highly variable due to the lagoon and islands on the backside. Positive differences (where the modern centerline is closer to the ocean) only occur in large values where transects bordered Ocracoke Inlet. In general, the type of change is uniform, which is representative of a barrier island in a natural setting. 


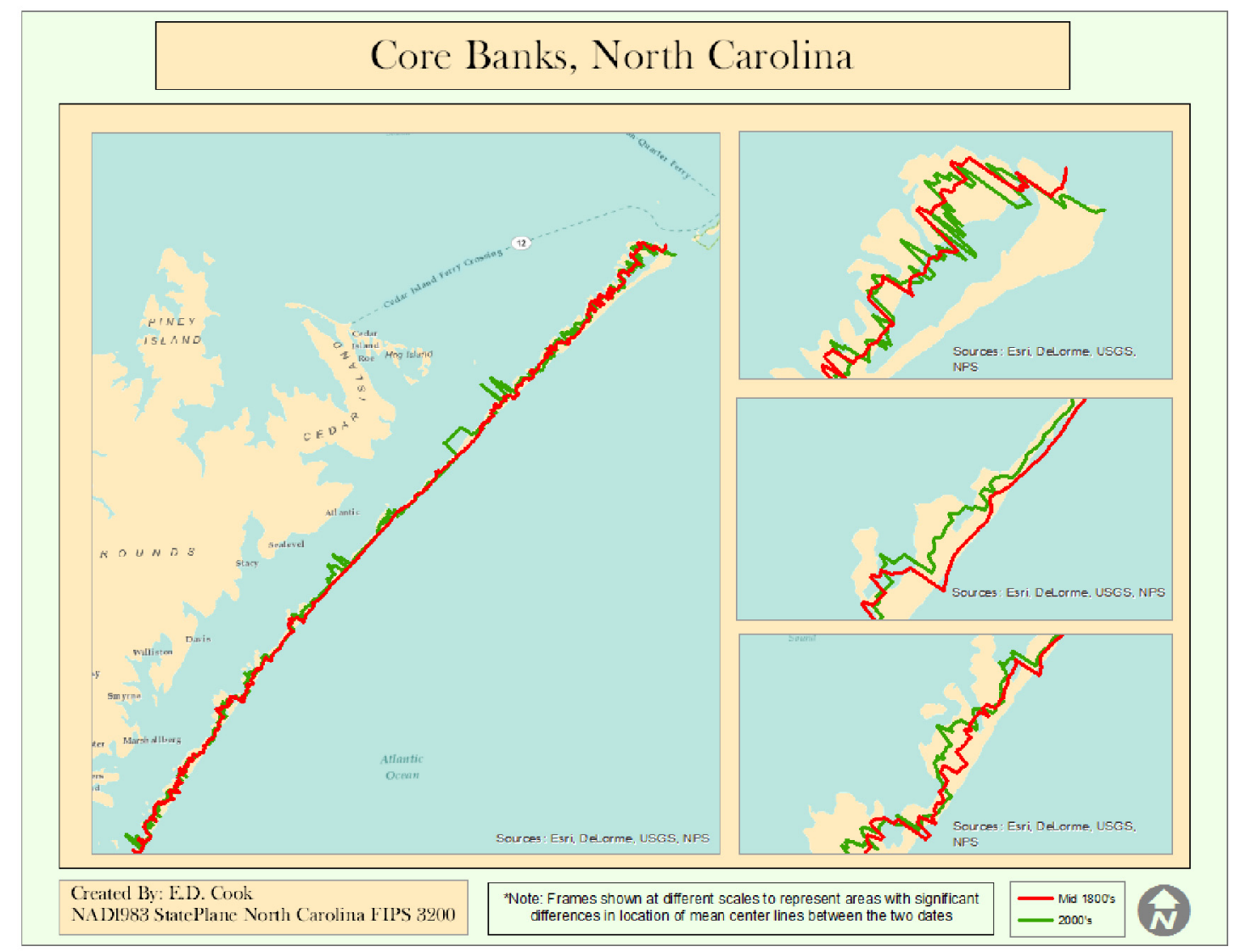

Figure 18: Mean Centerline locations, Core Banks

Mean Center line locations for each year with red representing its historic location. Significant variation is attributed to the presence of back barrier islands. The squared off section in green is a portion in which data was missing for the estuarine shoreline. 


\begin{tabular}{|c|c|c|}
\hline \multicolumn{4}{|c|}{ Net Mean Center Line Movement } \\
\hline Location & Average Change in Meters & Total Change \\
\hline Core Banks & 1.85 & 2201.62 \\
\hline & Max. Movement Inland & Max Movement Seaward \\
\cline { 2 - 3 } & -457.60 & 248.88 \\
\hline
\end{tabular}

\section{Table 12: Mean centerline change, Core Banks}

Difference in distance of mean center lines between two data sets. Negative values represent movement of modern centerline away from ocean shoreline. In total, 49.58 percent of transect centerlines demonstrated directional movement towards the bay.

\subsection{Cape Lookout to Shackleford Banks}

Cape Lookout is the second most southern cape in North Carolina, and is part of the Cape Lookout National Seashore. In comparison to the northernmost cape (Hatteras), Lookout is significantly smaller and does not have as extensive a dune field (a feature found on the complex barrier segments) as Hatteras does. It is also dominated by Barden Inlet immediately west. On the other side of the inlet is Shackleford Banks, which is the last segment more closely associated with the geology of the submerged river deltas found in the Core and Outer Banks. It extends west till it reaches Beaufort Inlet. Both locations are uninhabited, and exist in a more natural environment as there is little need to protect any infrastructure.

As with the rest of the study locations, change has been quite significant at certain locations, such is the case in Lookout and Shackleford Banks. There is general expansion of closed transects covering the tip of the cape and Lookout Shoals, and accretion on the south southwest ocean facing sections. Accretion is also evident as Beaufort Inlet has migrated in a westward direction. The Cape itself has seen a dramatic change in shape 
and location, effectively curving back to form Lookout Bight. Back barrier marsh islands have actually increased in size, while others have been newly created around Barden Inlet.

Cape Lookout has also experienced significant changes in transect widths. For the historic dataset, the average width was found to be 3,367 meters wide. The widest transect was 8,544 meters, and the narrowest was 897 meters wide. For modern day transects, the mean barrier island width is 2,724 meters wide, with an approximate maximum of 10,052 meters and a minimum of 714 meters. In total, the average length all transects in this location have reduced by about 19 percent. As some transects cross Barden Inlet, they may be outliers and their total lengths may not be completely representative.

Much of this can attributed to Lookout Bight, which is simply a curved segment of sand that is highly influenced by tidal, inlet, and wave factors. The opening of Barden Inlet resulted in a large decrease in transect area. 


\begin{tabular}{|c|c|c|}
\hline \multicolumn{3}{|c|}{ Change in Area by km2 } \\
\hline Location & Average Change & Total Change \\
\hline Cape Lookout & -0.03 & -25.88 \\
\hline & Max. Loss by Transect & Max Gain by Transect \\
\hline & -0.20 & 0.21 \\
\hline
\end{tabular}

\begin{tabular}{|c|c|c|}
\hline \multicolumn{3}{|c|}{ Change in Width Meters } \\
\hline Location & Average Change in Meters & Total Change \\
\hline Cape Lookout & -64.95 & -11105.61 \\
\hline & Max. Decrease & Max Increase \\
\hline & -402.55 & 689.54 \\
\hline
\end{tabular}

\section{Table 13: Change in total area for Cape Lookout}

For Cape Lookout, 75.68 percent of transects decreased in area. Approximately 86 percent decreased in area.

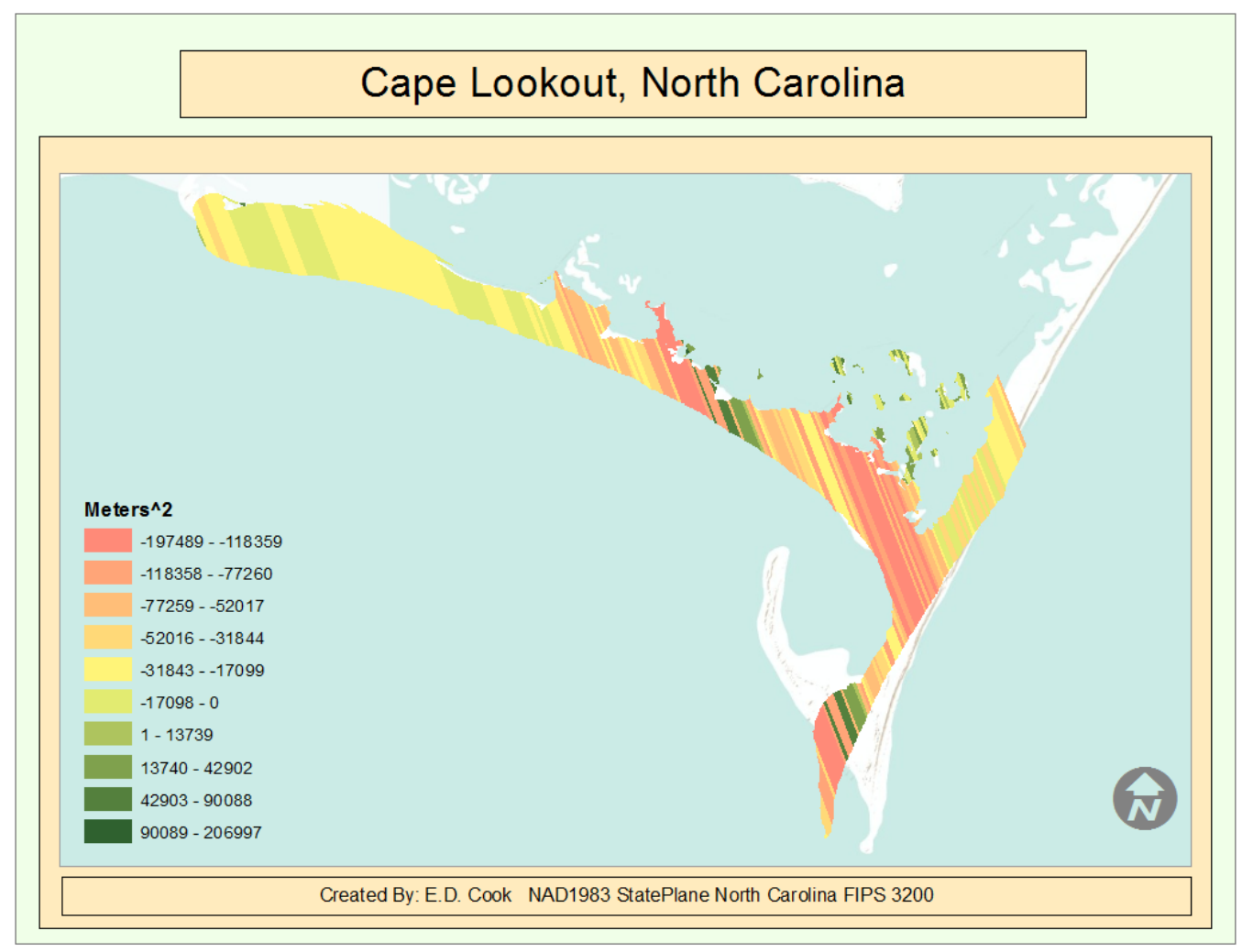

\section{Figure 19: Cape Lookout Transects}


The areas of change in Cape Lookout define similar characteristics in complex barrier islands. Locations of significant decreases for transects are found generally in the center of the map, with the area as a whole showing more transects reducing in area than in other segments.

\subsection{1: Mean Centerlines}

Positioning associated with areas found north of Cape Lookout shows the high variability of the centerlines for historic and modern datasets. This general pattern is due to the large amounts of back barrier marsh islands found along Core Sound. The variability does however, correspond for the two separate time series. Differences in the Shackleford Banks are not nearly as significant as well. Exceptions were present, as evident in the westernmost transects associated with the migrating Beaufort Inlet. 


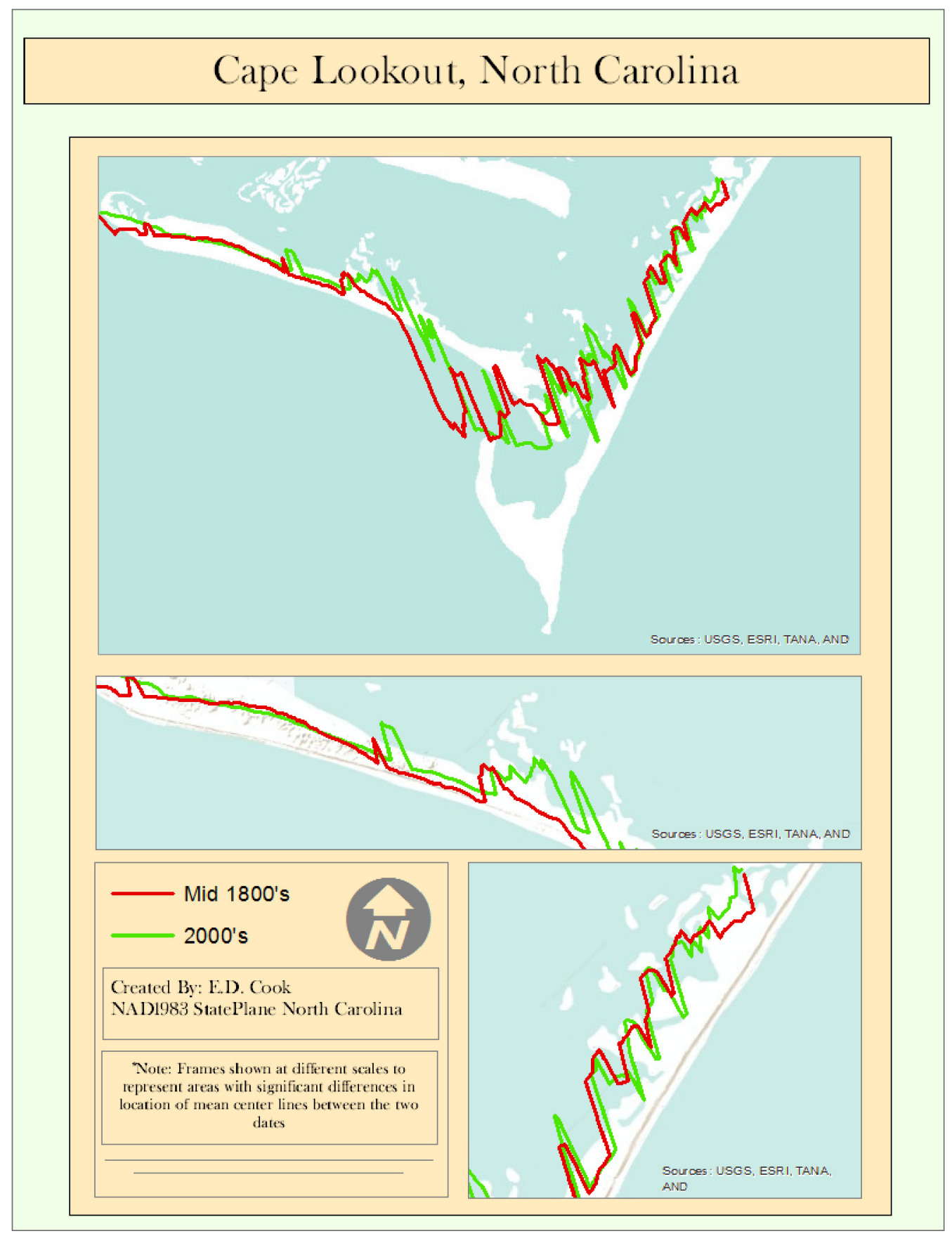

Figure 20: Mean centerline locations for Cape Lookout 


\begin{tabular}{|c|c|c|}
\hline \multicolumn{4}{|c|}{ Net Mean Center Line Movement } \\
\hline Location & Average Change in Meters & Total Change \\
\hline Cape Lookout & 31.26 & \\
\hline & Max. Movement Inland & Max Movement Seaward \\
\hline & -1052.30 & 7753.50 \\
\hline
\end{tabular}

\section{Table 14: Centerline Movement, Cape Lookout}

In total, 39.08 percent of the centerlines in transects are showing a condition where the modern center line is located closer to the bay than the historic dataset.

\section{7: Total Study Area}

In general, the stretch of barrier islands from Cape Lookout to the North CarolinaVirginia border has experienced a decrease in total area. Visually, there seems to be an apparent movement of the segments in a net landward direction. For all study locations with the exception of Cape Lookout, a majority of mean centerlines for the modern dataset shifted toward the bayside. All but Cape Hatteras returned average values that demonstrated this pattern. Out of the total number of transects in the study approximately 52.8 percent had modern centerlines that showed movement of the feature towards the bay. The weighted average based off the number of transects for each study area as a part of the whole shows that the average difference in distance between the modern and historical dataset is approximately -8.16 meters. 


\begin{tabular}{|c|c|c|}
\hline \multicolumn{3}{|c|}{ Change in Area by km2 } \\
\hline Location & Average Change & Total Change \\
\hline Total Study Area & -0.01 & -130.08 \\
\hline
\end{tabular}

\begin{tabular}{|c|c|c|}
\hline \multicolumn{3}{|c|}{ Change in Width Meters } \\
\hline Location & Average Change in Meters & Total Change \\
\hline Total Study Area & -82.46 & -620794.15 \\
\hline
\end{tabular}

\begin{tabular}{|c|r|r|}
\hline \multicolumn{3}{|c|}{ Net Mean Center Line Movement } \\
\hline Location & Average Change in Meters & \multicolumn{2}{c|}{ Total Change } \\
\hline Total Study Area & -8.16 & -227165.44 \\
\hline
\end{tabular}

\section{Table 15: Total Study Area Comparison}

Altogether, 73.85 percent of transects in the entire study area have decreased in area. 75.11 percent of these transects have decreased in width, while 52.79 percent have shown directional movement towards the bay.

\subsection{DISCUSSION}

Overall, the results found from this study coincide with present literature in terms of reduction in barrier island size. Smith et al. (2008), found a reduction in main barrier island width for the study locations of Pea Island and Avon-Buxton, and results corresponded with that study. The area north of Cape Hatteras is a known erosion hot spot, so reduction in size of this segment is generally well known. However, as a whole, the total reduction as a percentage of the study areas extent is quite significant.

In addition to these results, the mean centerlines are in fact showing that the present mid points of transects are located more towards the bayside. As a majority is present in the total number of transects demonstrating this behavior coupled with the mean distance, it is safe to conclude that the islands have shown signs of migration. The 
application of centerline position as a marker for analysis of historical dynamics provides a valuable point of reference, and should be developed further and utilized in similar studies researching barrier island change.

Positional accuracy of the T-sheets in relation to surrounding maps was a matter of concern. Standardized techniques of georeferencing were followed yet results differed from T-sheet datasets from the State of North Carolina, Dare County, Metric Mapping Project, and from the National Oceanic Service. Visual inspection showed locations of shorelines corresponded with all of the above, but differences as great as 40 meters in some locations were evident. Generally, the position of the author's shorelines fell within a midpoint of all 4 datasets. Quantification of this difference may be necessary as some results are close to this amount of error.

Additional considerations include the location and direction of transects. Issues of overlap were not a problem, as overlapping transects were removed. Including dissimilar features in one grouping (i.e. Cape Hatteras and the simpler barrier features) was a concern due to difficulty in distinguishing localized from broader trends, as the segments were very different in size and geology.

The purpose of this research was not to predict how the islands will react in the future, their response to past SLR rates may provide an insight about what type of change might be expected in the future. With a sea level rise rate of 0.2-0.4 meters in the last one hundred years, coupled with 47 hurricanes directly hitting the state of North Carolina from 1851-2004 (with only 1 a Category 4) (Blake et al., 2005), the likelihood of collapse occurring in the near future is minimal if barrier segments are allowed to progress in a 
more natural succession. Continued attempts to stabilize shores has resulted in barrier narrowing and decreases in area, with a decreased ability for segments to migrate towards the bay.

\subsection{CONCLUSION}

The barrier island changes in North Carolina were analyzed using historical Tsheets and aerial photography and digitized shorelines from 2009. The summary of the analysis is listed as follows:

\section{1: Currituck to Oregon Inlet}

Overall, the segments stretching from Oregon Inlet northward have shown significant change in decrease in area and width, and in mean centerline position. With the highest rates of relative SLR and subsidence, correlated with the more complex features found in this location, the result shows little variability and uniform distribution of change. This portion had the second highest percent of transect mean centerline movement.

\section{2: Oregon Inlet to Cape Hatteras}

Generally speaking, this portion is at a critical impasse. Continued prevention of natural processes in this study location has taken its toll, with large decreases in size and highly variable change. Although there is little subsidence relative to northern portions found in Currituck Sound, the high storm frequency and long distance from the mainland leaves this strand of barrier segments extremely vulnerable. Migration is present in most transects, but the islands themselves are decreasing in total area. 


\section{3: Cape Hatteras}

The patterns of change found on Cape Hatteras in general vary from the transects found elsewhere. Movement of the mean centerline is away from the bay, but this is mainly due to the accretion on southward facing portions. Distinctions between the cape and the simpler barrier segments associated with it must be made. These portions are similar to most other stretches of the study area, demonstrating a slight directional movement towards the bay and a general decrease in both width and area.

\section{4: Ocracoke Island}

Ocracoke Island has remained relatively uniform through the time of this study. Although there has been significant variability in change, the sediments are being relocated due to wave action and inlet processes due to the allowance of this portion to follow a natural progression. A little more than half of all transects have seen movement

of their mean centerlines towards the bay. The removal of $2 \mathrm{~km}^{2}$ of land is also associated with the inlet processes, as sediment is being removed from the ocean shore and deposited in the tidal deltas. Over time, if the inlet is not maintained, these deltas will create new back barrier marsh islands.

\section{5: Core Banks}

The Core Banks share some characteristics with the surrounding study areas. These characteristics are: high variability located nearby the maintained inlets, addition of back bay marsh islands where inlets were allowed to form and close on their own, and a decrease in total area. Comparatively speaking the Core Banks are a experiencing a less change than other portions of the study area. 


\section{6: Cape Lookout to Shackleford Banks}

The southernmost portion of the study area is also demonstrating a similar type of change as compared to other study locations. Relative SLR rates are much lower in this section of the state; the differences in total area and centerline positioning are evidence of land loss, with modern features representing 77 percent of land represented in the Tsheets and evidence of regression by an average movement towards the bayside of 63 meters per a transect mean center. These values are likely skewed by the inclusion of the Cape in this study area, as the Shackleford Banks showed general stability.

\section{7: Total Study Area}

The type of change occurring in the study area's extent seems to be highly dependent on location and the type of the barrier island. The locations that were nearest to maintained inlets showed significant narrowing, which may be influenced by movement of the inlet itself. Visual inspection also reveals the possibility of an inverse function related to decrease in area as distance from an inlet increases. This is evidenced by the narrowing of portions in the middle of Core Banks, Ocracoke, and Avon north of Hatteras.

The Core Banks and areas north of Oregon Inlet seem to demonstrate the least variability of all study locations, with the lowest difference in transect area through the time series. This relative stability is likely the result of natural processes occurring in the Core Banks and the different geology and higher elevations in areas north of Oregon Inlet (i.e. Kitty Hawk, Kill Devil Hills). Nevertheless, these areas do show some signs of 
migration, with the modern centerline generally being located closer to the bayside than the historic centerline. 


\section{Bibliography}

Blake, E.S., Rappaport, E.N., Jarrell, J.D., Landsea, C.W. (2005). The deadliest, costliest, and most intense United States tropical cyclones from 1851-2004 (and other frequently requested hurricane facts). NOAA Technical Memorandum NWS TPC-4.

Campbell, T. J., \& Benedet, L. (2004). Beach nourishment magnitudes and trends in the US. Journal of Coastal Research, 39.

Church, J. A., \& White, N. J. (2006). A 20th century acceleration in global sea-level rise. Geophysical research letters, 33(1), L01602.

Clark, W. B., Miller, B. L., Stephenson, L., Johnson, L., \& Parker, H. N. (1912). The Coastal Plain of North Carolina (Vol. III). Raleigh, N.C.: E.M. Uzzell \& Co.

Croft, L.P., 1934, Study for a national seaside, including Kill Devil Hills, Hatteras, Cape Lookout, Fort Macon area: Branch of Planning, National Park Service

Crowell, M., Leatherman, S. P., \& Buckley, M. K. (1991). Historical shoreline change: error analysis and mapping accuracy. Journal of Coastal Research (7)3, 839-852.

Crowell, M., Leatherman, S. P., \& Buckley, M. K. (1993). Shoreline change rate analysis: long term versus short term data. Shore and Beach, 61(2), 13-20.

Culver, S. J., Ames, D. V., Corbett, D. R., Mallinson, D. J., Riggs, S. R., Smith, C. G., \& Vance, D. J. (2006). Foraminiferal and Sedimentary Record of Late Holocene Barrier Island Evolution, Pea Island, North Carolina: The Role of Storm Overwash, Inlet Processes, and Anthropogenic Modification. Journal of Coastal Research, 22(4), 836-846.

Culver, S. J., Grand Pre, C. A., Mallinson, D., Riggs, S. R., Corbett, D. R., Foley, J., ... Twamley, D. (2001). Late Holocene barrier island collapse: Outer Banks, North Carolina, USA. The Sedimentary Record, 5(4), 4.

Daniels, R. C., \& Huxford, R. H. (2001). An error assessment of vector data derived from scanned National Ocean Service topographic sheets. Journal of Coastal Research 17(3), 611-619.

Dolan, Robert. (1986). The Outer Banks of North Carolina. U.S. Geological Survey Professional Paper, 1117-B, 47.

Donnelly, C., Kraus, N., \& Larson, M. (2006). State of Knowledge on Measurement and Modeling of Coastal Overwash. Journal of Coastal Research, 22(4), 965-991.

Douglas, B. C. (1992). Global sea level acceleration. Journal of Geophysical Research: Oceans (1978-2012), 97(C8), 12699-12706. 
Dunbar, G.S., 1958, Historical geography of the North Carolina Outer Banks: Baton Rouge, Lousiana, Lousiana State University Press, 234 p.

Everts, C. H., Battley, J. P., Gibson, P. N., Engineers, U. S. A. C. of Engineers, Station, U. S. A. E. W. E.Station, NOAA, . (1983). Shoreline Movements: Report 1: Cape Henry, Virginia, to Cape Hatteras, North Carolina, 1849-1980. U.S. Army Engineer Waterways Experiment Station. Retrieved from http://books.google.com/books?id=KaNMOAAACAAJ

Fenster, M. S., \& Dolan, R. (1993). Historical shoreline trends along the outer banks, North Carolina: processes and responses. Journal of Coastal Research 9(1), 172-188.

Godfrey, P. J., \& Godfrey, M. M. (1973). Comparison of ecological and geomorphic interactions between altered and unaltered barrier island systems in North Carolina. Coastal Geomorphology. State University, New York, NY, 239-257.

Grand Pre, C., Culver, S. J., Mallinson, D. J., Farrell, K. M., Corbett, D. R., Horton, B. P, Hillier, C., Riggs, S.R., Snyder, S.W., Buzas, M. A. (2011). Rapid Holocene coastal change revealed by high-resolution micropaleontological analysis, Pamlico Sound, North Carolina, USA. Quaternary Research, 76(3), 319-334.

Kemp, A. C., Horton, B. P., Culver, S. J., Corbett, D. R., van de Plassche, O., Gehrels, W. R., ... Parnell, A. C. (2009). Timing and magnitude of recent accelerated sea-level rise (North Carolina, United States). Geology, 37(11), 1035-1038.

Kleckley, J. (2012). Economic Outlook for the Outer Banks, NC. The Outer Banks Chamber of Commerce. Retrieved October 29, 2012

Kraus, N., Militello, A., \& Todoroff, G. (2002). Barrier Breaching Processes and Barrier Spit Breach, Stone Lagoon, California. Shore \& Beach, 70(4).

Kraus, Nicholas C, \& Wamsley, T. V. (2003). Coastal Barrier Breaching, Part 1: Overview of Breaching Processes (No. ERDR/CHL CHETN-IV-56). US Army Corps of Engineers.

Leatherman, S. P. (1979). Migration of Assateague Island, Maryland, by inlet and overwash processes. Geology, 7(2), 104-107.

Leatherman, S. P. (1988). Barrier island handbook. Laboratory for Coastal Research, University of Maryland College Park, Maryland

Leatherman, S. P., \& Eskandary, L. S. (1999). Evaluation of coastal erosion hazards along Delaware's Atlantic Coast. Journal of Coastal Research SI(28), 43-49.

Mallinson, D. J., Culver, S. J., Riggs, S. R., Walsh, J. P., Ames, D. V., \& Smith, C. W. (2008). Past, Present and Future Inlets of the Outer Banks Barrier Islands, North Carolina. 
Mallinson, D. J., Riggs, S. R., Thieler, E. R., Culver, S. J., Farrell, K., Foster, D. S., Horton, B., Wehmiller, J. F. Late Neogene and Quaternary evolution of the northern Albemarle Embayment (mid-Atlantic continental margin, USA. Marine Geology 217(1-2), 97-117

North Carolina Sea-Level Rise Assessment Report. (2010). N.C. Coastal Resources Commissions's Science Panel on Coastal Hazards.

Overton, M., Grenier Jr, R., Judge, E., \& Fisher, J. (1999). Identification and analysis of coastal erosion hazard areas: Dare and Brunswick Counties, North Carolina. Journal of Coastal Research SI(28), 69-84.

Pajak, M. J., \& Leatherman, S. (2002). The high water line as shoreline indicator. Journal of Coastal Research 18(2), 329-337.

Pierce, J.W. (1969), Sediment budget along a barrier island chain: Sedimentary Geology 3, 516

Pilkey, O.H., W.J. Neal, S.R. Riggs, C.A. Webb, D.M. Bush, J. Bullock, and B. Cowan, (1998), The North Carolina Shore and Its Barrier Islands: Duke University Press, Durham, $\mathrm{NC}, 318 \mathrm{p}$.

Pompe, J. J. (1999). Establishing fees for beach protection: paying for a public good. Coastal Management, 27(1), 57-67.

Reed, A. (2012, June 6). North Carolina Lawmakers Pass 4-Year Ban on Sea Level Policy Changes. Insurance Journal. Retrieved from http://www.insurancejournal.com/news/southeast/2012/07/06/254672.htm

Riggs, S.R., Ames, D. V., Culver, S. J., Mallinson, D. J., Corbett, D. R., \& Walsh, J. P. (2009). Eye of a human hurricane: Pea Island, Oregon Inlet, and Bodie Island, northern Outer Banks, North Carolina. Geological Society of America Special Papers, 460, 43-72.

Riggs, Stanley R, Ames, D. V., Culver, S. J., \& Mallinson, D. J. (2011). The battle for North Carolina's coast: evolutionary history, present crisis, and vision for the future. Chapel Hill: University of North Carolina Press.

Riggs, Stanley R, \& Ames, D. W. (2009, November 15). Impact of the Oregon Inlet terminal groin on downstream beaches of Pea Island, NC Outer Banks. White Paper.

Riggs, Stanley R, Culver, S. J., Ames, D. W., Mallinson, D., Corbett, D. R., \& Walsh, J. P. (2008). North Carolina's coasts in crisis: a vision for the future. White Paper.

Sallenger Jr, A. H. (2000). Storm impact scale for barrier islands. Journal of Coastal Research $16(3), 890-895$. 
Shalowitz, A. L., \& Reed, M. (1962). Shore and Sea Boundaries: With Special Reference to the Interpretation and Use of Coast and Geoditic Survey Data. United States Department of Commerce, Coast and Geodetic Survey.

Smith, C. G., Culver, S. J., Riggs, S. R., Ames, D., Corbett, D. R., \& Mallinson, D. (2008). Geospatial Analysis of Barrier Island Width of Two Segments of the Outer Banks, North Carolina, USA: Anthropogenic Curtailment of Natural Self-Sustaining Processes. Journal of Coastal Research, 24(1), 70-83.

Vincent, S.H., 2003, Cape Hatteras Light Station, Cape Hatteras National Seashore: Cultural Landscape Report: Manteo, North Carolina, U.S. National Park Service, 54 p.

Wamsley, T. V., \& Kraus, N. C. (2005). Coastal Barrier Island Breaching, Part 2: Mechanical Breaching and Beach Closure (No. ERDC/CHL CHETN-IV-65). US Army Corps of Engineers.

Withers, A., \& Queram, K. E. (2012, December 4). Dredging, beach nourishment projects underway in Southeastern N.C. Star News Online. Wilmingtion, NC. Retrieved from http://www.starnewsonline.com/article/20121204/ARTICLES/121209902/1177?Title=Dr edging-beach-nourishment-projects-under-way-in-Southeastern-N-C-

Zervas, C. (2004). North Carolina Bathymetry/Topography Sea Level Rise Project: Determination of Sea Level Trends (NOAA Technical No. NOS CO-OPS 041) (p. 31). NOAA. Retrieved from http://tidesandcurrents.noaa.gov/publications/techrpt41.pdf

Zhang, K., Douglas, B. C., \& Leatherman, S. P. (2004). Global warming and coastal erosion. Climatic Change, 64(1), 41-58.

Zhang, Keqi, Douglas, B. C., \& Leatherman, S. P. (2001). Beach erosion potential for severe nor'easters. Journal of Coastal Research 17(2), 309-321.

Zhang, K., and S. Leatherman. 2011. Barrier Island Population along the US Atlantic and Gulf Coasts. Journal of Coastal Research 27:356-363. 